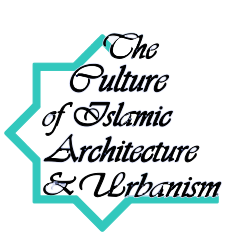

\title{
Historic Urban Landscape Approach: A New Tool for Urban Heritage Management
}

\author{
Sanaz Jafarpour Nasser ${ }^{1 *}$, Eisa Esfanjary Kenari ${ }^{2}$, Manouchehr Tabibian ${ }^{3}$ \\ 1. PhD Candidate in Architectural and Urban Conservation, Art University of Isfahan, Iran. \\ 2. Assistant Professor of Architectural and Urban Conservation, Art University of Isfahan. \\ 3. Professor of Urban Design \& Planning, University of Tehran, Iran. \\ (Received 16 Mar 2020, Accepted 9 Jun 2020)
}

The phenomenon of rapid urbanization and transformation of existing cities has put the conservation of heritage areas in the core of urban planning agenda. However, the traditional notions of monuments, groups of buildings or city sections, identifying them as separate entities within a wider urban context, is no longer sufficient to protect the characteristics and qualities of heritage from fragmentation, degeneration and subtraction of significance. Therefore, there was a transformation in both concept and scale of conservation, aroused from the challenges in this field, and as a consequence, a new approach to deal with properties in territorial scale, the Historic Urban Landscape, emerged. This approach moves the consideration of urban areas into an ecological framework, and accepts a dynamic rather than static view of cultural heritage in general, and urban heritage in particular. On 10 November 2011 UNESCO's General Conference adopted the new Recommendation on the Historic Urban Landscape (HUL) by acclamation, the first by UNESCO regarding urban heritage since 1976 (UNESCO 1976), aiming to facilitate the integration of heritage management and urban development. This Recommendation promotes a landscapebased approach, in which the existence of an inventory of resources and the identification of values and vulnerabilities are essential factors when drawing up urban development policies. Likewise, particular emphasis is placed, not only on the involvement of different disciplines but also on the role of other stakeholders and the community in heritage management and consequently in urban development where relevant. The HUL concept is not limited to the physical and spatial organization of the urban territory and its surroundings; it can also refer to social and cultural practices, economic processes, as well as other intangible dimensions of heritage. The HUL approach is an answer to the management of historic cities under new forms of development pressure with the main goal to preserve the significance and qualities of the city itself. In fact, the question in HUL should be about "historic urban landscape concept and approach," which aims at preserving the quality of the human environment. There is an important role for all actors in gaining an understanding of the HUL concept and approach, and then developing and applying tools and best practices to implement this important guidance. The outcomes of applying the HUL approach include continuity of historic urban identity as part of daily life, thriving social interaction and economic activity, and environmental quality in historic settlements of all types. The HUL approach can aid in achieving these objectives. These goals can be achieved by applying the four tools through a six steps action plan that is circular in nature. In this way, the research aims to study the significance of the HUL concept and approach, gives answer to "what HUL is about" and "how can it be used in urban heritage management," using qualitative content analysis technique. This paper, addressing the UNESCO (2011) Recommendation, is structured as an explication employing sections of the HUL text with discussions of their meaning and import. Discussions are used to express the implications and diversity of applications of this important statement on the urban future.

Keywords: Historical Urban Landscape (HUL), Paradigm shift in urban conservation, Urban heritage, Landscape approach, Change management.

\footnotetext{
${ }^{*}$ Corresponding author. E-mail: s.jafarpour@aui.ac.ir
} 


\section{رويكرد منظر شهرى تاريخى ابزارى جديد براى مديريت ميراث شهرى}

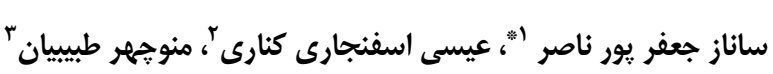

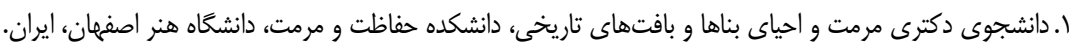

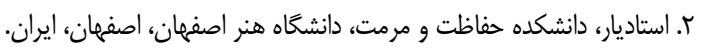

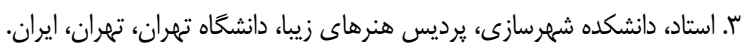

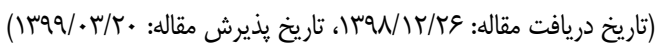

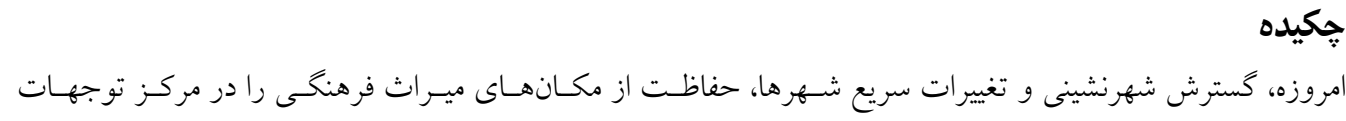

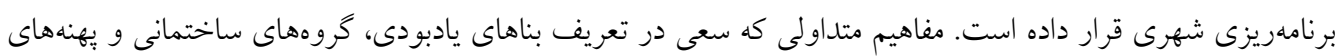

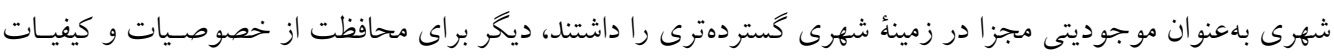

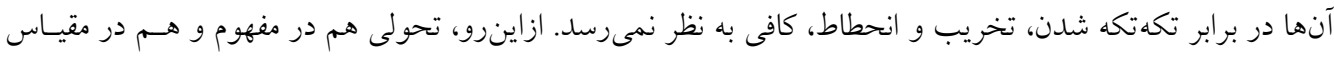

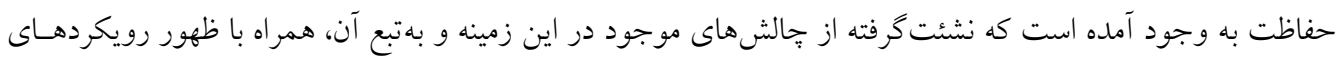

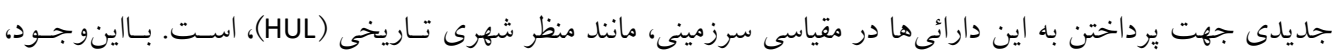

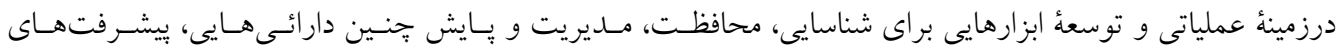

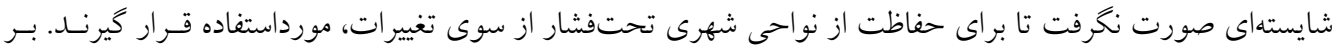

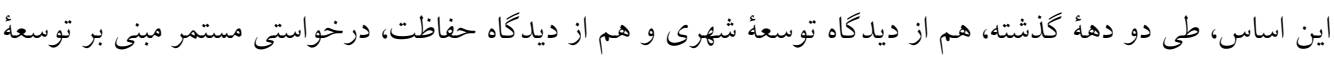

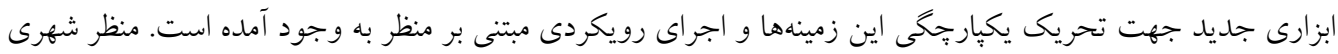

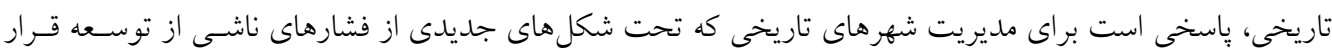
دارند، با اين هدف اصلى كه منزلت و كيفيت زندكى شهرى حفظ شود. ازاينرو، در اين يزووهش سعى شده است تا بـا بـا

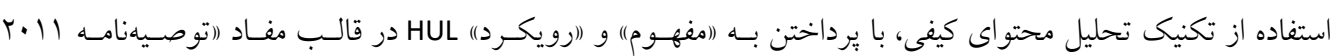

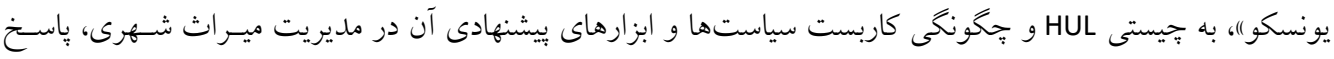

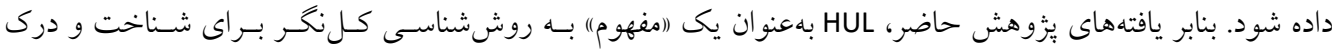

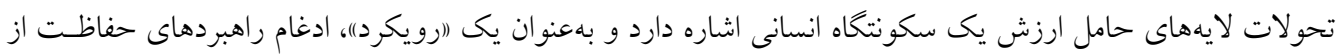
منابع ميراثى را در سياستها و برنامهاى توسعه شهرى مدنظر قرار داده است.

وازَّان كليدى منظر شهرى تاريخى (HUL)، تغيير بارادايم در حفاظت شهرى، ميراث شهرى، رويكرد مبتنى بر منظر، مديريت تغيير در منابع ميراثى. s.jafarpour@aui.ac.ir : : نويسندة مسئول مكاتبات" 
(5 \& 10

با مطرح شدن مفهوم (منظر) بـهمثابـه يـك ((فراينـد مولـد فرهنگ)" بهجـاى يـك (محصـول منـتج از فرهنــ)، تمركـز

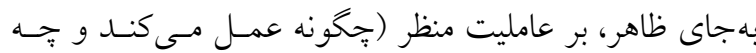
مى كند) واقع شــ (Corner 1999, 4; Taylor et al. 2015, 2). اين رويكرد جديد، طى دهـهـــاى اخيـر، بـر اسـاس نخـاهى كلانمقياس بـه محسيطِ شـهرى و سـرزمينى شهر، بـهـعــوان

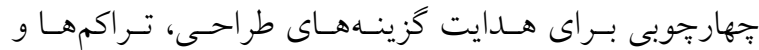
تركيب عملكردهـا تـا انتخـاب دقيـق مصـالح و راهكارهــاى يايدارى موردتوجه بوده است. علاقه شديد ايسن رويكـرد بـهـ زمينهُ شهر و بُعد سرزمينى آن، جايى كه ضوابطش از آن منـتج مىشوند، آن را نهفقط در توسعهُ شهرى، بلكه در مورد احيـاء

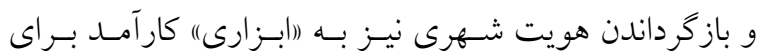
برخى از بغرنجترين مسائل شهرسازى معاصـر بـــل كـرد. بــه اين معنا، لايههاى تــاريخى شـهر - بـهـعنـوان زمينـهاى بسـيار

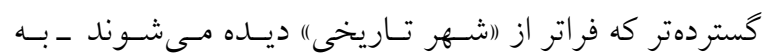

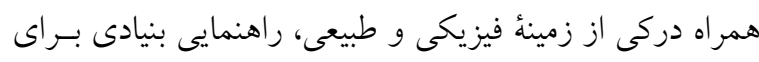
طراحى را نمايان مى كنند (Bandarin 2015, 9).

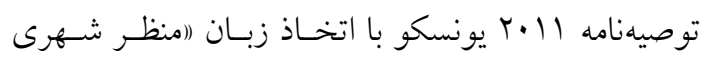
تاريخى")، ضمن گنجاندن زمينه كستردهترى در قلمرو اجرايى

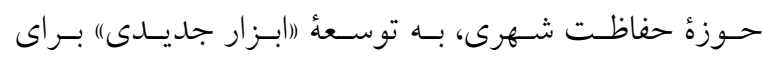
محافظــت از نــواحى شـهرى تـاريخى انجاميـــ. حركــت از (يادمانها) به ((شهرهاى زنده)) بهعنوان جايكزينى بـر اى تفكـر

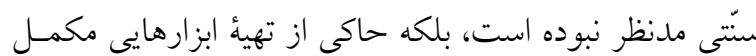
براى تعريف فرايندى بهتر جهت كنجاندن (زمينـه)) و (بسـتر)" يادمانها و لايهبندى شهـر در برنامسهريـزى و تصسميمسـازى است. بالين حال، افزوده شدن ابعاد يك شهر زنده بـه يادمـان، حفاظت شهرى را به تعامل مقيـاسهـاى مختلـف سـوق داد (Turner 2013, 79) وازهة (احفاظت شهرى) قابل مشاهده است: (احفاظت شهرى بــه محافظت از بناهاى منفرد محدود نمسىشـود، بلكـهـ بـا تبــيل
طـى دهـهـهـاى اخيـر، سـرعت برشـتاب و خــارج از كنتـرل

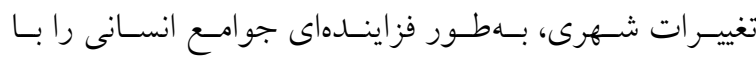

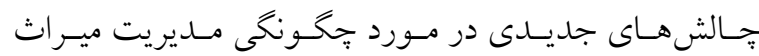
شهرى مواجه كرده است. ديخر، ميراث شهرى را نمسى تـوان بهنونان يكى واقعيت مجزا، محدوده محصورى كه بـهواسـهه طرحها و ضوابط از نيروهـاى بيرونسى تغييـر در امـان مانـده، تصور كـرد (Bandarin 2015, 15). در ايسن رويكـرد سـنتى، مديريت ميراث شهرى همواره بر حفظ ((بافت)) برجـاىمانـده از كذشته، براى نسل هاى آينده متمركز بوده است ( Zancheti

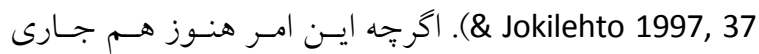
هست، باين حال تغييرى قطعى در (انديشهُ حفاظـت شـهرى)" روىداده است. در نيمه دوم قرن بيستم، نظريههـاى حفاظـت

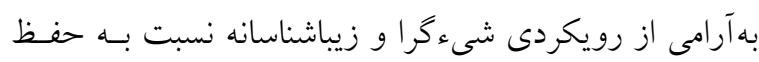

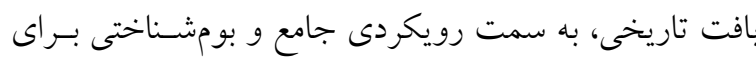
مديريت (امنابع ميراثى) تغيير كرد (Smith 2015, 187). در جنسين وضـعيت در حسال تغييـرى، (امــديريت منـابع

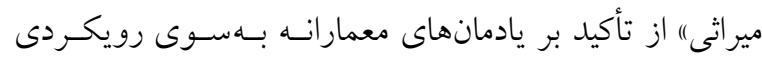

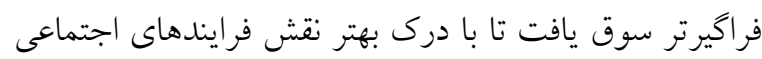
و اقتصادى در حفاظت از ارزشهاى شهرى، مفـاهيمى ماننـد

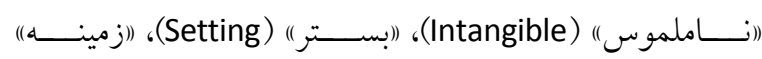

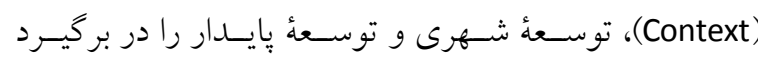
Pendlebury ؛Fairclough et al. 2008 ؛Jokilehto 2007) Bandarin and van :Taylor and Lennon 2012 2009 (Oers 2012, 2015 . تصويب (اتوصسيهنامـهاى در بـاب منظـر

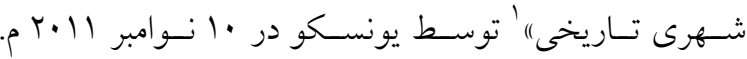
ماحصل جنين تغيير وِارادايمى است. اين توصيهنامسه، بـا بهـره كرفتن از (رويكرد منظر) بهعنوان رويكردى فراخيـر، كوشـيده

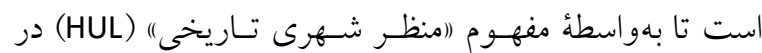
جهارجوب كلى توسعهُ پايدار، بنيانى براى رويكردى جـامع و

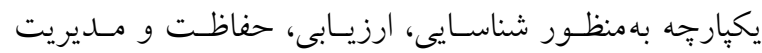

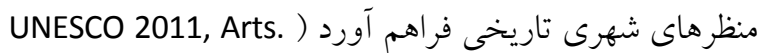


1975, Art.1

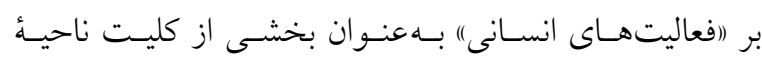

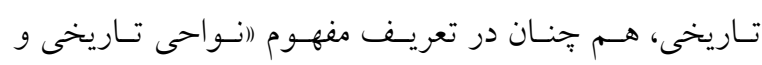

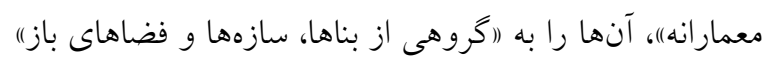

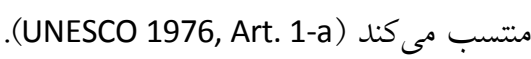

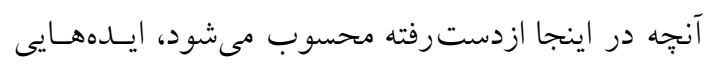

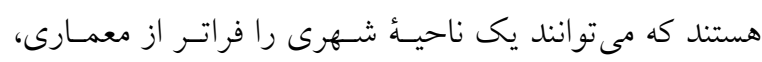

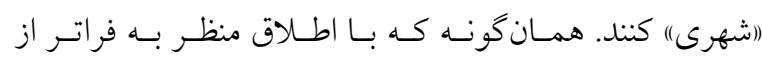

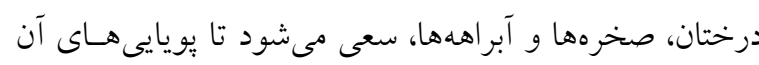
بـهنهـوان يـك (امنظـر)" درك شـود (Jokilehto 2007, 28).

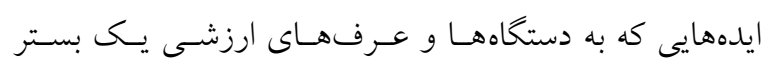

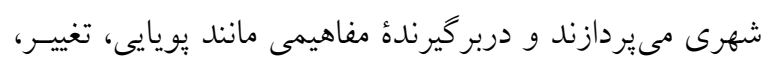

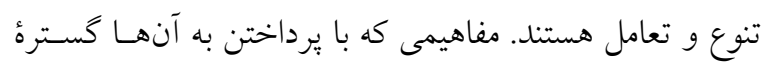

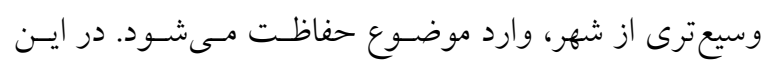

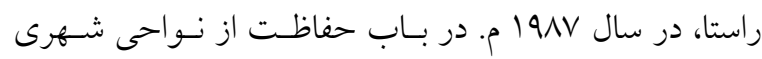

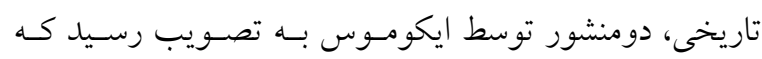

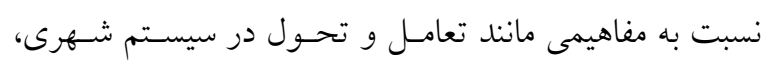

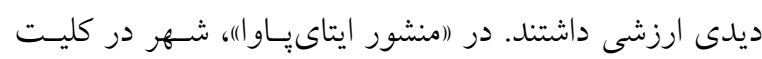

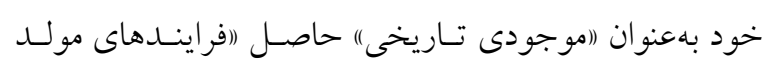

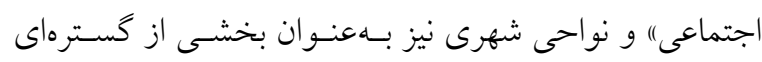

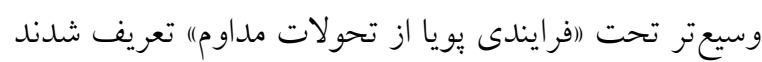
(ICOMOS Brazil 1987, Arts. 1-3) با تأكيد بر امر (امشاركت)،، علاوه بـر سـاختار كالبــى شـهر،

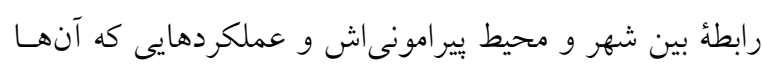

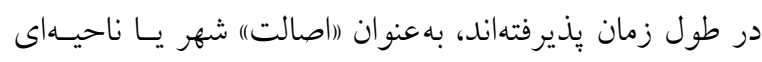
تاريخى قلمداد شد (ICOMOS 1987, Art.1).

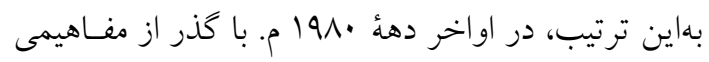

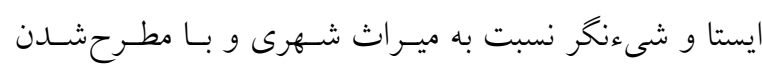

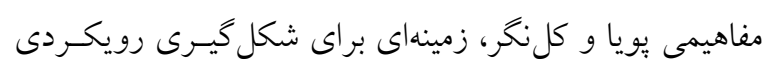

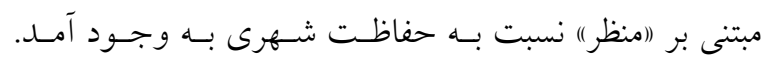

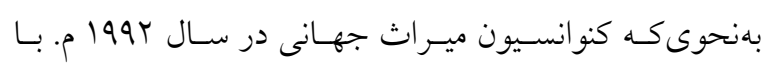

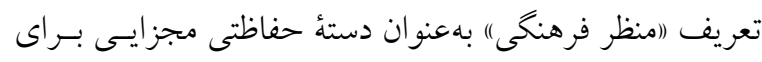

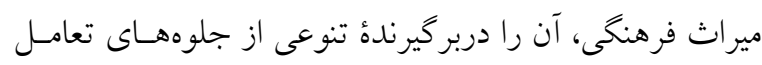

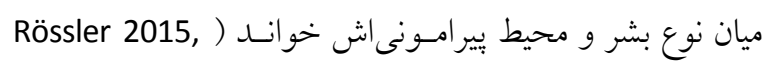

كردن كل محيط شهرى به منظومهاى بيجيديده و جندو جهى، بـه

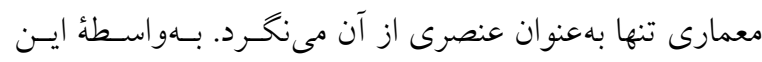

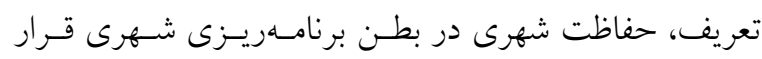

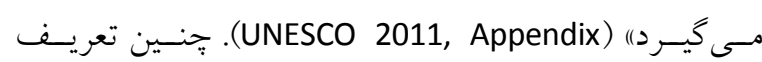
فراكيرى از موضوع (احفاظت شهرى)، باز مفهومسـازى شـــه

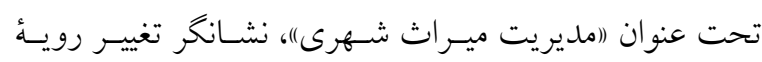

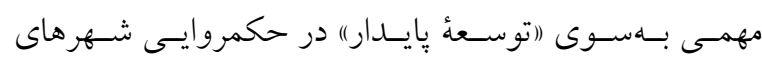
تاريخى است (Bandarin and van Oers 2012, 63).

كذر از شىء به منظر در نظرية حفاظت شهرى

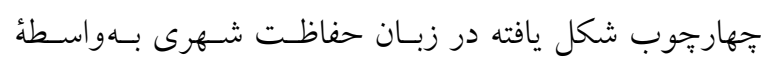

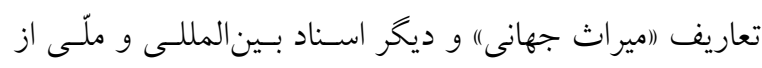

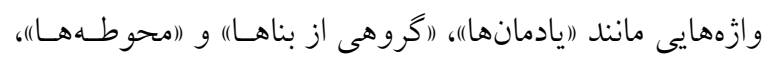

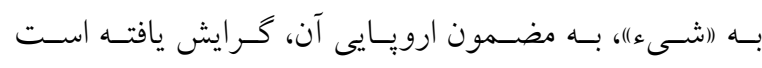

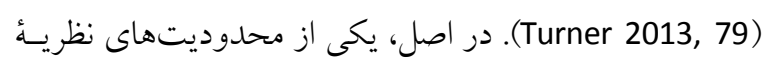

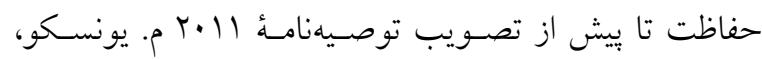

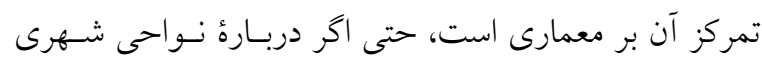

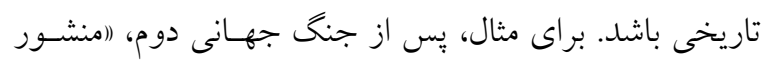

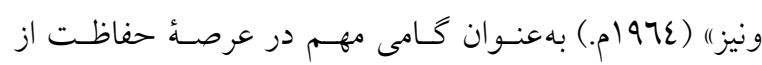

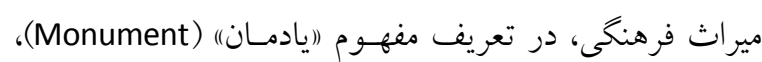

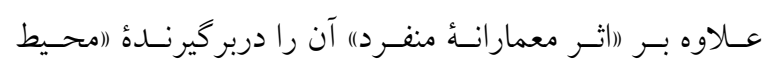

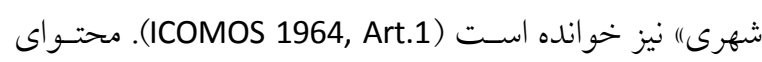

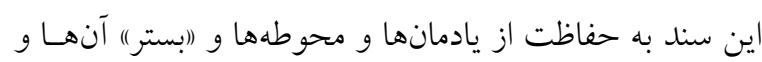

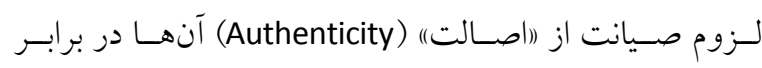

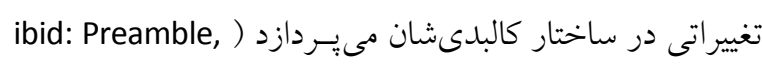

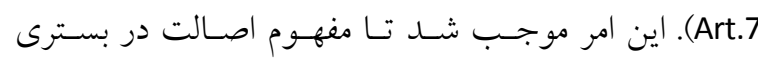

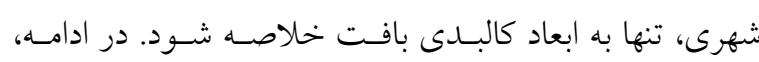

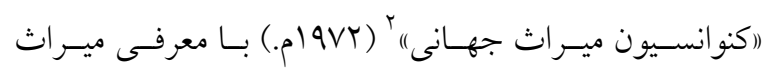

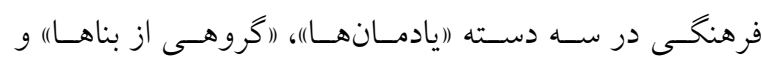

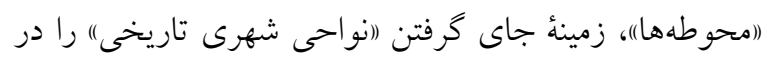
دستؤ (آكروهى از بناها) فراهم كـرد (UNESCO 1972, Art.1)

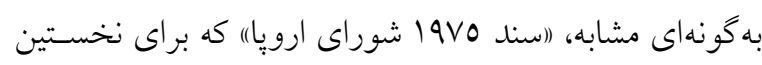

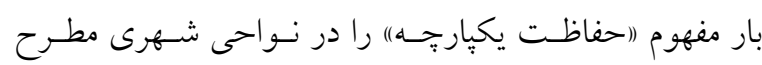

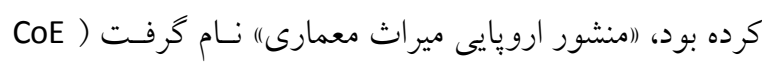


79)، توسعهُ ابزارهاى مديريتى كه شناسايى، ارزيابى و كـاهش

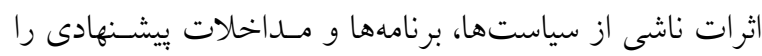
بر مجموعة شهرى تاريخى، ممكن مى سازد. درنتيجها، بنـا بـهـ

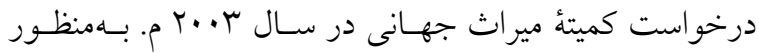

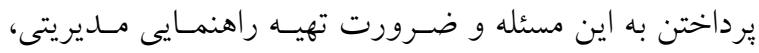
كنفر انسى با موضوع (ميراث جهانى و معمارى معاصر)) در ماه

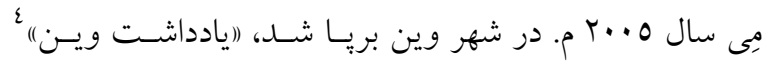

حاصل اين كنفر انس است (UNESCO 2005, Preamble). يادداشـت ويـن بــهنــوان (اسـندى انتقـالى)، از تغييـرى

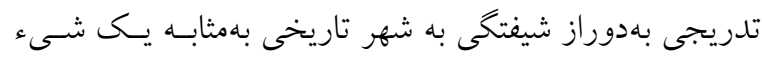

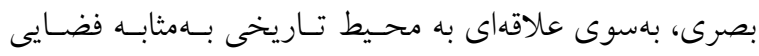

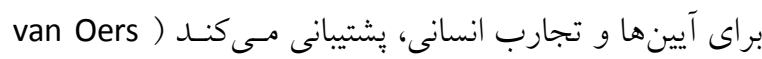

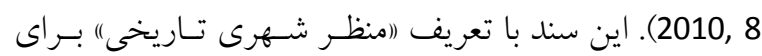

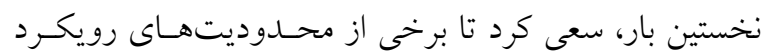

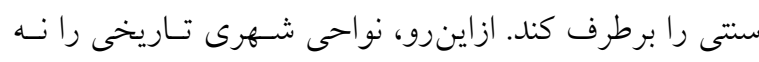

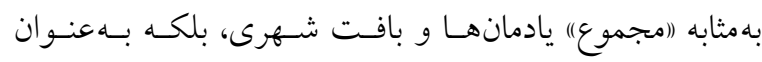

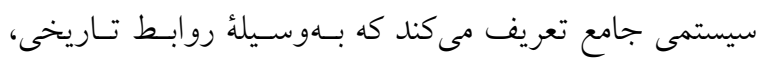

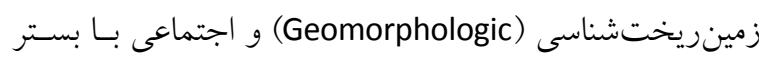

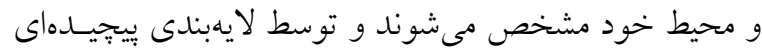

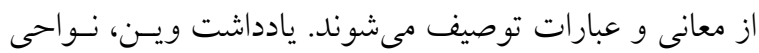

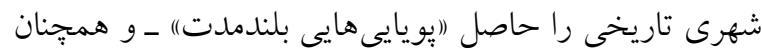

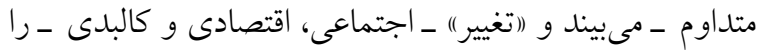

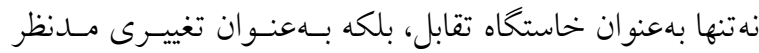
قرار مى مهد كه بايد درك و مـديريت شـود ( Bandarin and .(van Oers 2012, 72

بهاين ترتيب، از اواخر دهأ •199 م؛ و در دهأ نخست از قرن بيست و يكم، با توسعة مفهوم مير اث شهرى، حوزهٔ عمل

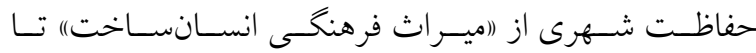
(فر ايندهاى يكى ساختار شهرى) در حال كسترش بوده اسـت.

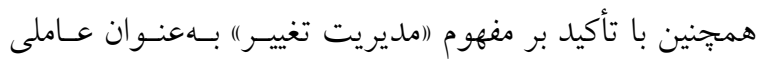

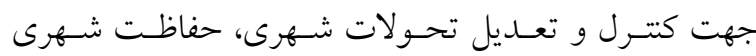

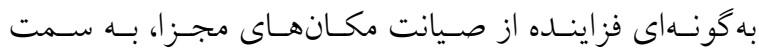

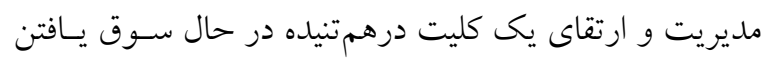

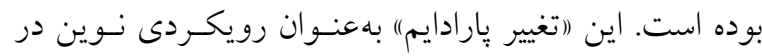

31). دهؤ •199 م. رامىتوان نقطـهُ عطفى در بسطط مفهـوم

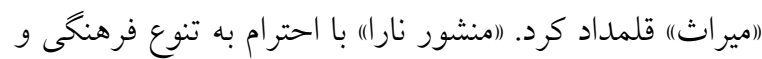
جنبهاى ملموس و نـاملموس ميـراث، بـه مفهـوم (اصـالت)

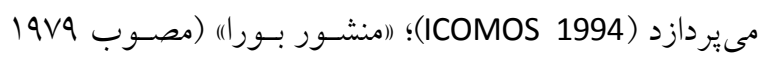

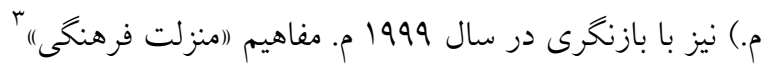

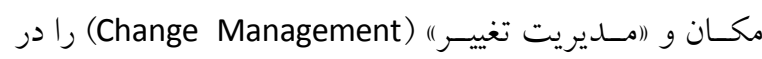

فرايند حفاظت تبيين مى كند (Australia ICOMOS 1999).

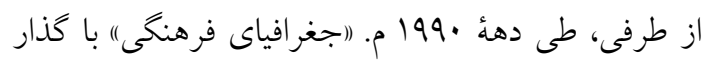

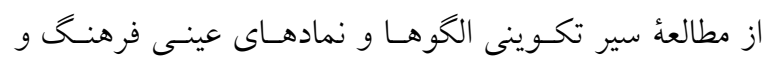

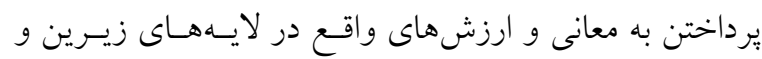

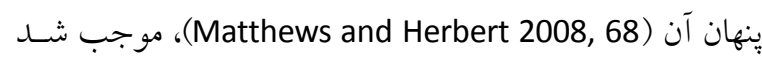
تا (رويكرد منظر) علاوه بر ميراث ملموس، ميـراث نـاملموس (ترس

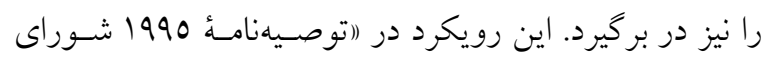

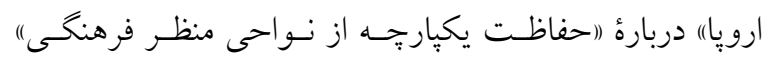

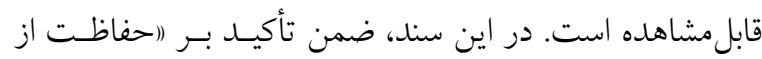

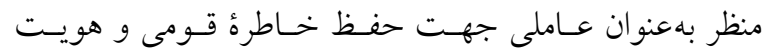
فرهنگى جوامع بشرى)، بهمنظور (احراست از منافع فرهنخسى،

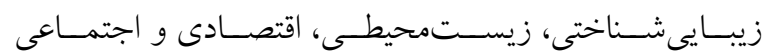

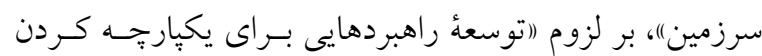

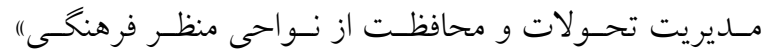

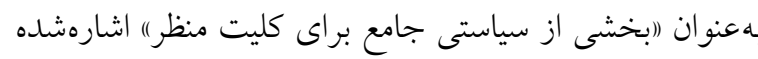
است (CoE 1995, Preamble).

\section{تغيير :ارادايم در نظرية حفاظت شهرى}

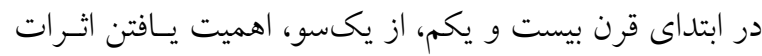

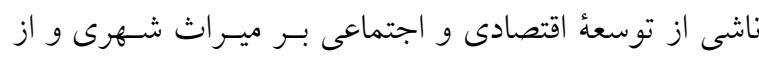

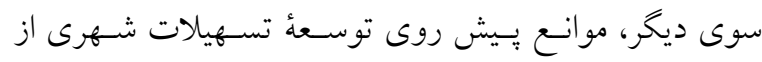

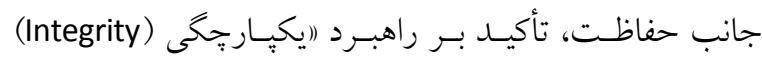

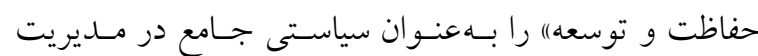

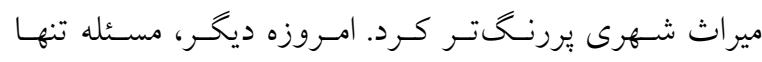

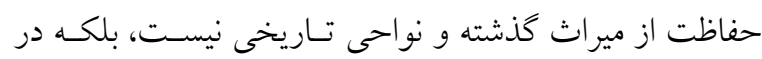
مورد زمينهسازى توسعة جديد استت (Esfanjary 2017, 34).

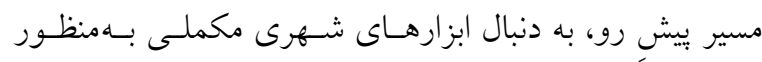
حفاظت شهرى با زبانى انعطاف يذيرتر است ( Turner 2013 
(Bandarin and van Oers 2012, 195) (ازنجاكه دو موضوع يادشده، بر (انظريه)) و (اجراى) رويكرد منظر شهرى -تـاريخى اشاره دارند، بهمنظور بيى بردن به فحواى سند حاضر و فراينـــ

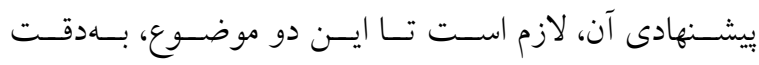
موردبررسى قرار كيرند. ازاينرو، در اين يزوهش سـعى شـده

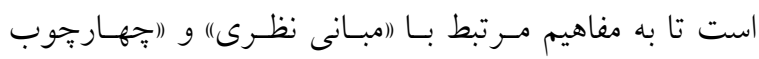

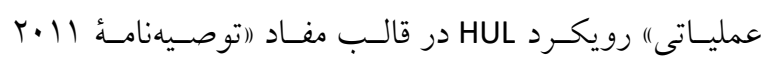

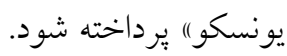

كدها را بهطور اسـتقرائى توليـــ مسى كنتـد. ايـن امـر موجــب

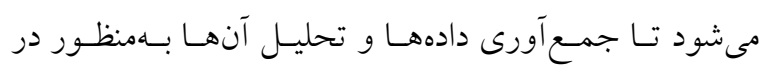
بركرفتن متن و نكات ظريف آن، بهطور همزمان و به شـكلى منعطف، صورت كيـرد (Drisko and Maschi 2016, 85-87). بهبيانديخر، در اين روش، منبع كدها بهجاى آنكه برگرفتـه از

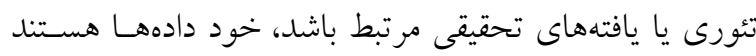

.(Hsieh and Shannon 2005, 1286) محققان در كدگذارى استقرائى، نخست با بيرون كشـيدن مطالب متنى كه به بهترين وجسه معنـاى محتـواى موجـود در

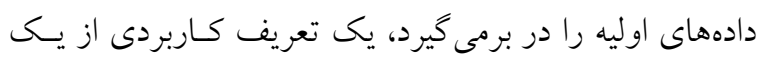

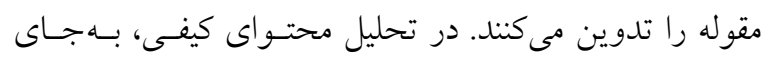
تمركز بر توسعة مفهومى، (اكدگذارى بـاز)) موردتوجسه اسـت.

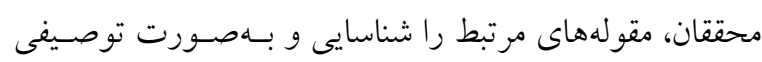

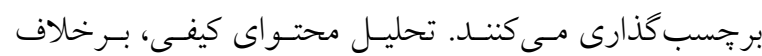
"(تئورى بنيادى) كه به توسعةُ مفاهيم و نظريه مىيــردازد، يـى روش تحقيق توصيفى است كه محصول آن، اغلب مقولههـا و مضامين توصيفى هستند. بهاين ترتيب، تحليل محتواى كيفى رونى

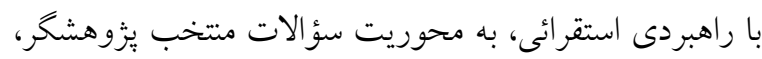

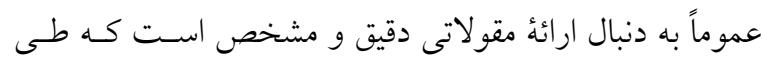
يك فر آيند تعاملى و جرخهـهُ بـازخورد، بـازنكرى و تصسحيح

مىشود (Drisko and Maschi 2016, 104 \& (2).

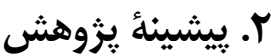

درزمينه مفهوم و رويكرد منظر شهرى تاريخى، آثـار متعـددى لئىو

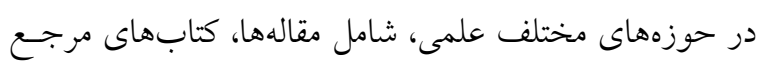

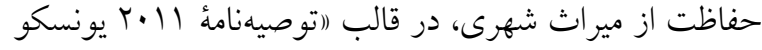
دربارهٔ منظر شهرى تاريخى") يذيرفته شد. رويكرد HUL با بركزارى سلسله جلسـات كارشناسـان

در نقاط مختلفى از جهان و در دفتر مركزى يونسكو، از سـال

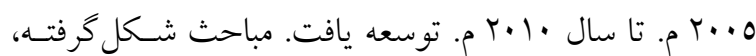

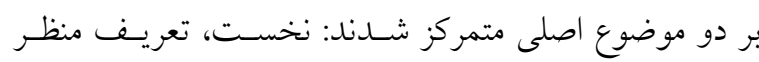

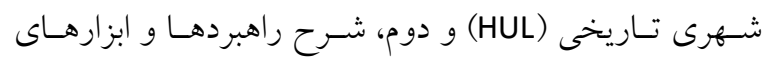

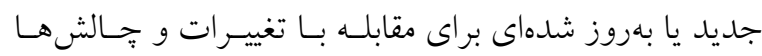

\section{ا. روش يزوهش}

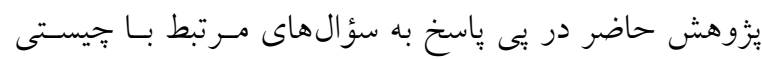

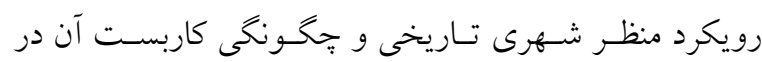
مديريت ميراث شهرى است. ازاينرو، روش تحقيق بر مبنـاى محتواى برسش هاى تحقيق و نيل به هدف، داراى رويكـردى

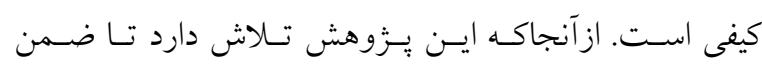

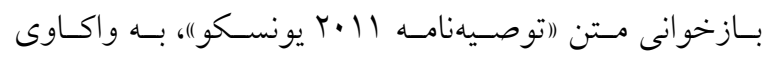
محتواى سند و توصيف مضامين كليدى آن بيردازد، بهمنظور ييش برد فرايند تحقيق از تكنيك (تحليل محتسواى كيفى)" بـا

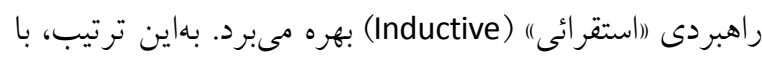
ارجاع به بخش هايى از متن توصيهنامسه، بـهـ توصسيف مفهـوم

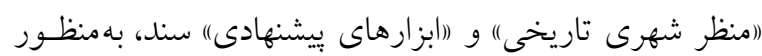
بيادهسازى آن برداختهشده است. ("تحليل محتواى كيفى)، مجموعهاى از تكنيـكهــا بـراى تحليل نظاممند انواع مختلفى از متنها اسـت كـه نـه تنهـا بـهـ محتواى آشكار بلكه به مضامين و ايدههـاى نهـان موجـود در متنها نيز بهعنوان محتواى اصلى، مى يردازد. تحليـل محتـواى كيفى درصدد بسط دادههاى متنى است بر مبناى آنجه بر آنها استوار است. در تقابل با خواست تقليل گراى تحليل محتـواى كمّى (يايسهاى)، تحليـل محتـواى كيفى ممكـن اسـت عمـلاً

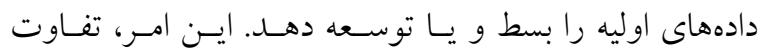
كليدى ميان تحليـل محتـواى كيفى بـا رويكردهــاى كمّى و

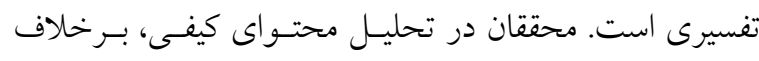
تحليل محتواى كمّىى، بـهـهـاى اسـتفاده از كـدهاى توليـدى قياسى بركرفته از تئورى و يافتههـاى تحقيقى قبلى، عمومـاً 
جديد، يذيراى قدرت ميراث فرهنكى است تـا Instrument شهرها و سكونتخاهها را ازنظر فرهنكى، زنده، ازنظر اقتصادى، يررونق، ازنظر اجتماعى، فراگير و ازنظر زيستمحيطى، يايدار

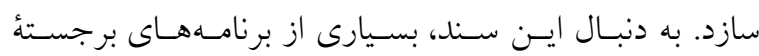

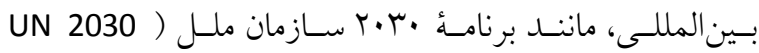
Agenda

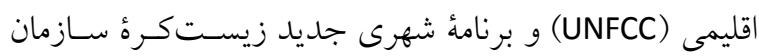
ملل (UN-Habitat New Urban Agenda) در دستور كار قرار كرفتند (UNESCO 2019, 5). در ("ييشخفتار)) و (مقدمةٔ) توصسيهنامسه، ضـمن اشـاره بـهـ

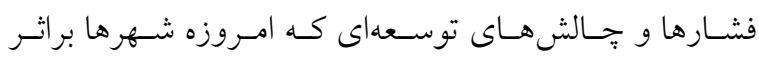

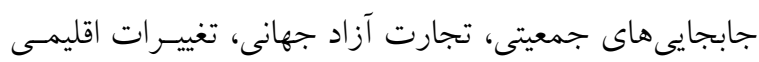

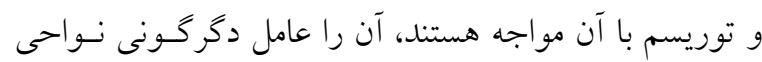

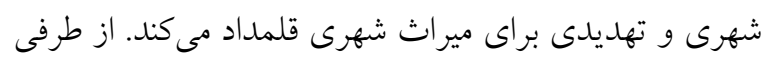

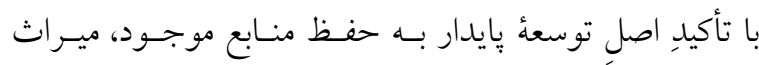

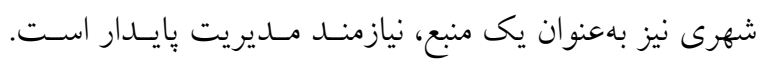

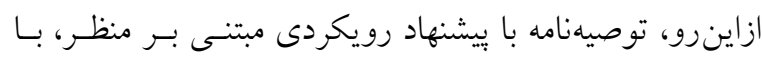

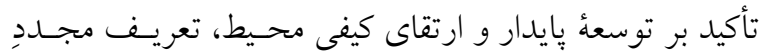
نقش ميراث شهرى در جامعه و ادغـام راهبردهـاى مــديريت، حفاظـتـ و برنامــهريــزى نــواحى شــهرى تــاريخى را در فرايندهاى تصميمسازى و توسعهُ محلى مدنظر دارد. بخش نخست توصيهنامه، (اتعاريف))، به تعريف مفهـوم و رويكرد HUL مى يردازد. وازهة (منظر شهرى تاريخى)، هــم بــر يك (مفهوم)) و هم بر يك (رويكرد)) دلالـت دارد. بخـش دوم توصيهنامه، ("جالشها و فرصتهاى بيش روى HULال)، ضـمن

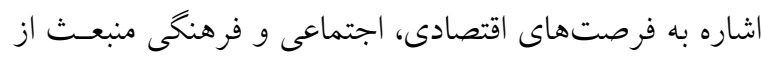
فشـارهاى جديـا ((شهرنشـينى و جهـانى شـدن))، (توسـعه)) و

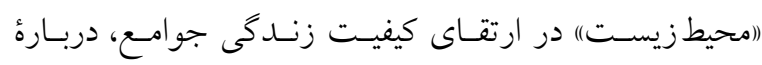

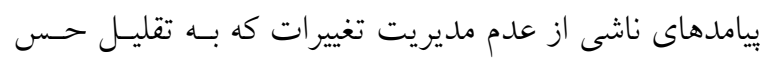

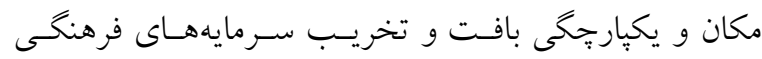
مى انجامد، هشدار مى دهد.

بخش سوم توصيهنامه، (اسياستها) و بخـش جهـارم آن،

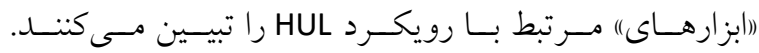
سياستهاى ارائه شـده در توصـيهنامـه، بـه محوريـت ادغـام

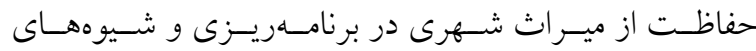

و رسـالههـاى دكتـرى، بــه طبـع رسـيدهانـــ كـهـهـ بـر مفهـوم بينرشتهاى HUL دلالت داشتهانـــ. در حـوزة مـرور ادبيـات، كتـاب (امنظـر شـهرى تــاريخى: مــــيريت ميـراث در قــرن

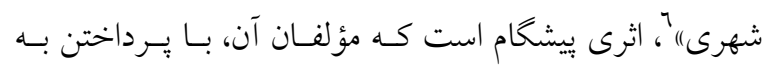
تعاريف، اهداف، جِالشها و ابزارهاى بيشـنهادى توصسيهنامـهُ

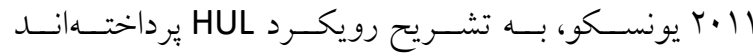

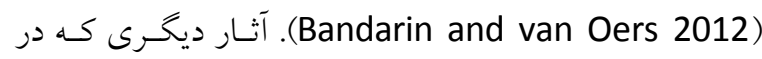
آنها ضمن مرور ادبيات به نوآورىها، يافتهها و افقهاى ييش van Oers ) روى اين رويكرد اشارهشده است، عبارتاند ازئ Bandarin and van Oers and Haraguchi 2010 Angrisano ؛ Esfanjary 2017 :Sonkoly 2017 2015

(et al. 2017

رويكرد شش مرحلهاى HUL، در متن نهايى توصسيهنامسه

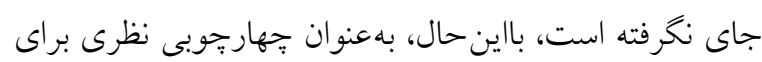
اجرا، در قالب يـى راهنمـا توسـط بخـش آموزشىى ميـراث جهانى توسعه يافتـه اسـت (WHITRAP 2016). بانسـرين و

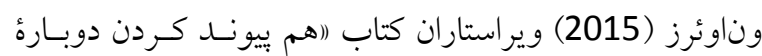
شهر)، به تشـريح و تبيسين رويكـرد شـش مرحلـهاى HUL و

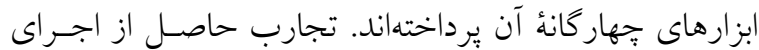
رويكرد منظر شهرى تاريخى در شهرهاى ميراث جهانى، طى نـ يك دهؤ اخير، در اثرى با نام (اتغيير شـكل حفاظـت شهـرى: رويكرد منظر شهرى تاريخى در عمل) كه شامل گزارشهايى

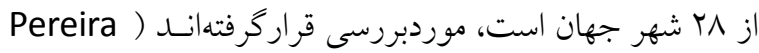
2019 دانشخاههاى ايران نيـز جنـــين رسـالهُ دكتـرى دربـاره تبيسين جهارجوبى براى حفاظت از منظر شهرى تـاريخى بـه تـأليف رسيدهاند (Eshrati 2012; Kiani Dehkiani 2015).

\section{r. توصيهنامة منظر شمرى تاريخى}

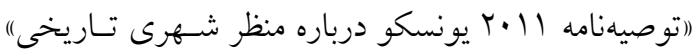
(يس ازاين با عنوان (توصيهنامه)) مورداشاره قرار مسى گيـرد) از كشورهاى عضو مى خواهـــ تـا حفاظـت و مـــيريت ميـراث فرهنكى واقع در شهرها و سـكونتخاههـا را بـا سياسـتهـا و

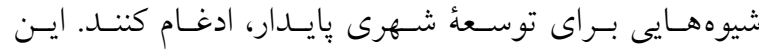
Standard-setting ( توصيهنامه بهعنوان ابزار تبيينكنتدهُ معيار 
|(منظر شهرى تاريخى، ناحيهاى شهرى است كه بهعنـوان

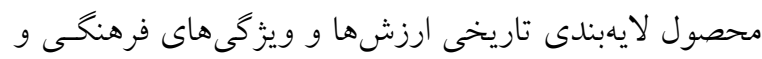

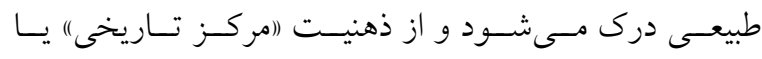
(امجموعه) فراتر مىرود تا زمينة شهـرى گسـتردهتـر و بسـتر

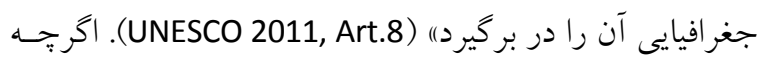

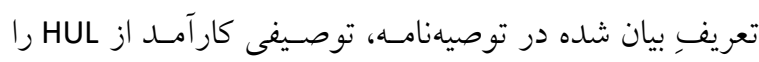

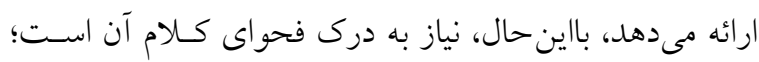
اينكه (الايهبندى ارزشها) به جه معنا است؟ در تعريف HUL، وازٔه (لالايهبندى) به مفهوم (منظر) اشـاره

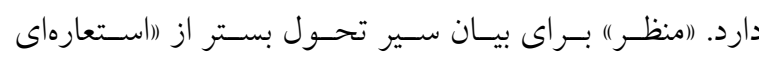

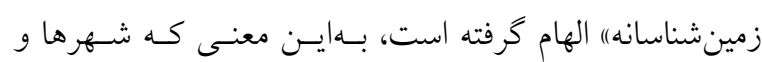

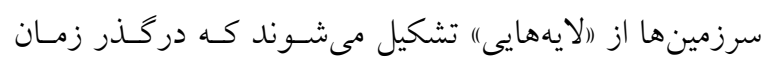

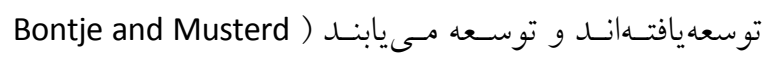

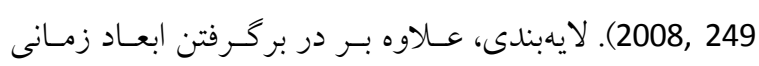

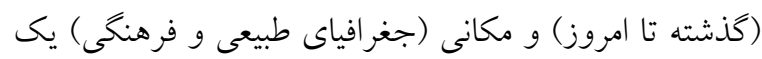

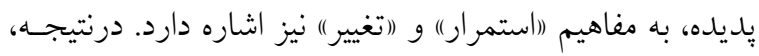
منظر شهرى تاريخى، محصول يكى فرايند است، محصولى كه همواره دستخوش تغيير است.

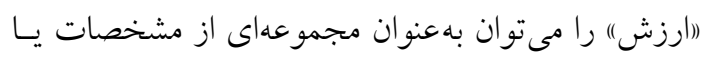

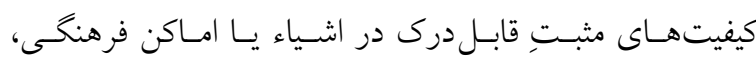

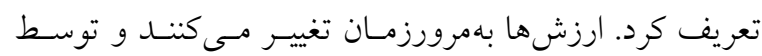

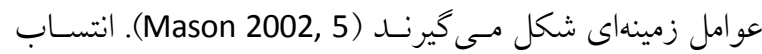
نسبى و اجتماعى كيفيتها به اشياء است كه موجب مسى لهـود

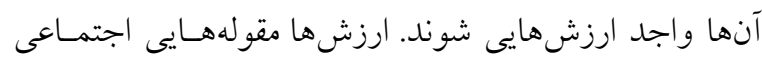

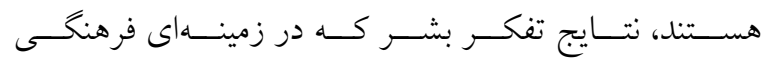

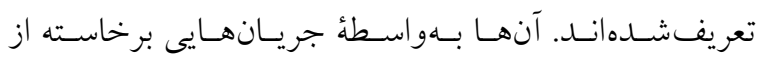

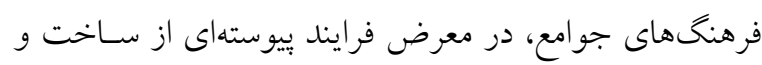

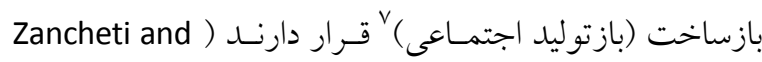
.(Jokilehto 1997, 40

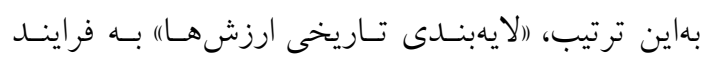

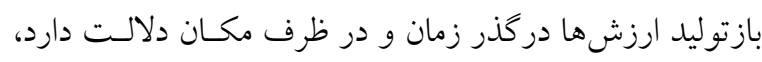

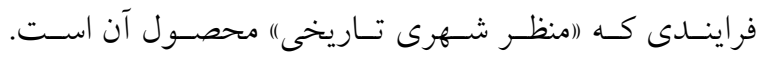

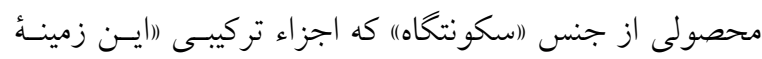

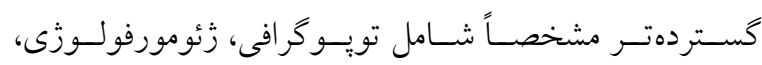

سياست كذارى كلان سرزمينى، به نقش ذىنقـان در سطوح

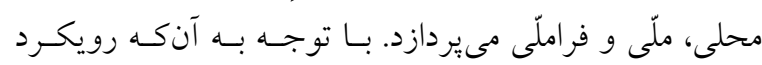

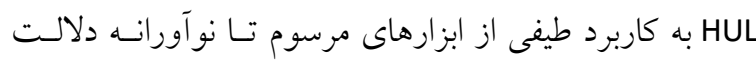

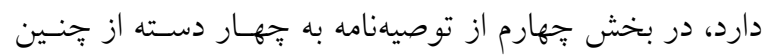

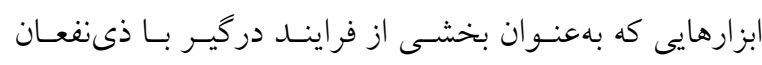

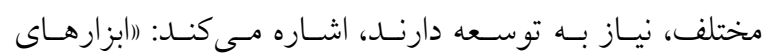

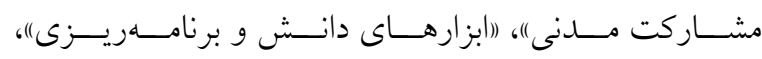

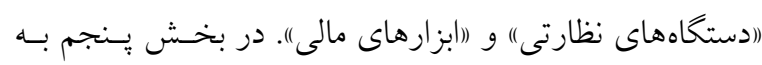

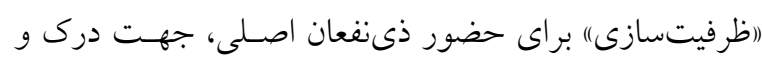

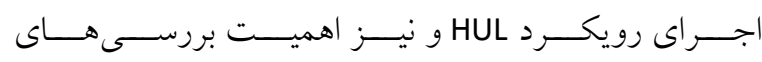

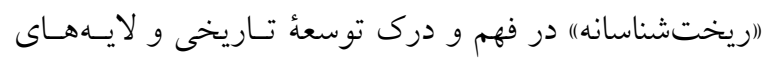

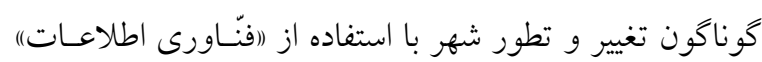

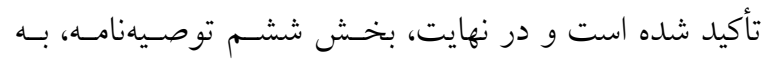

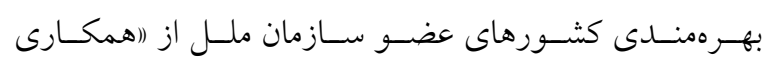

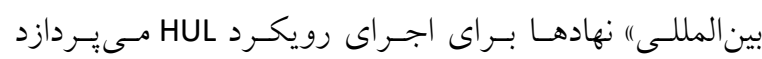

.(UNESCO, 2011)

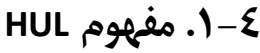

مفهوم امروزى حفاظت ميراث شـهرى، از يـك بنـاى منفــده،

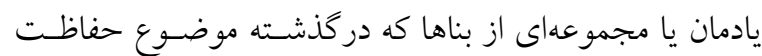

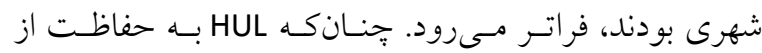

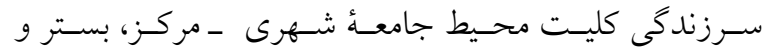

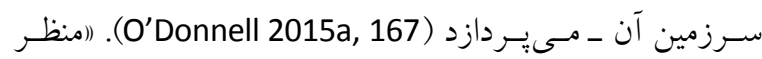

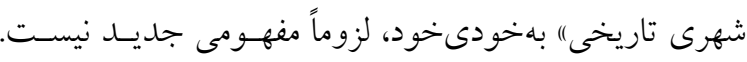

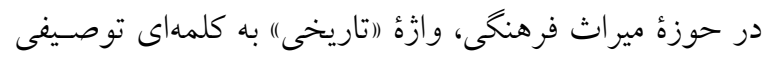
به معناى واجدِ كيفياتِ (ميراث) تبديل مىشود. (امنظر شهرى)" بهو اسطةٌ مفهوم (منظر) ) با اشاره به يويايى هاى شهرى، بهعنوان

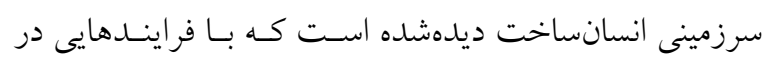

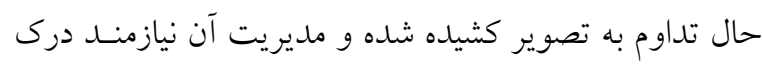

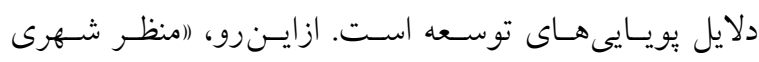

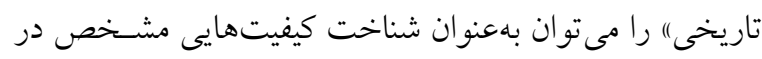
سرزمينها يا محوطههايى شهرى كه تاريخى قلمداد شدهانـا،

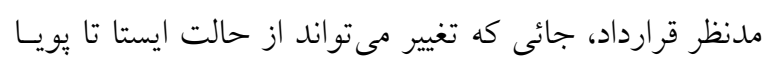
در سير باشد (Jokilehto 2007, 31-33). 
بهاين ترتيب، مفهوم HUL با اشاره به لايههاى ملمـوس و

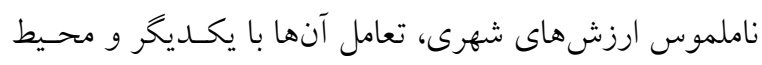

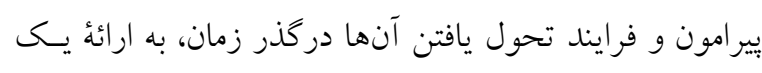

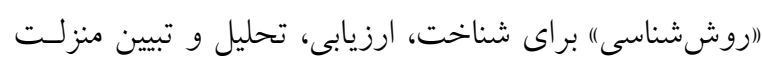
منابع ميراث شهرى مى يردازد.

\section{HUL}

رويكردهاى شكل كرفته در حفاظت شهرى، مشخصـاً از قـرن

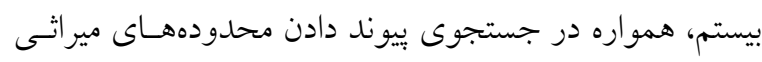

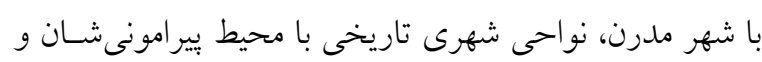

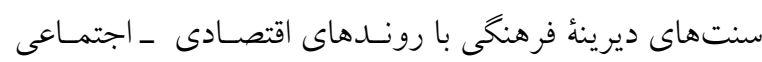

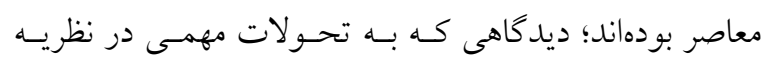

و شيوء (Theory)

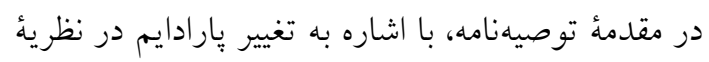

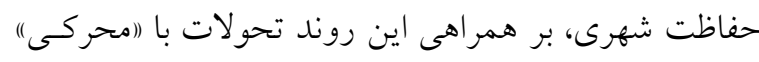

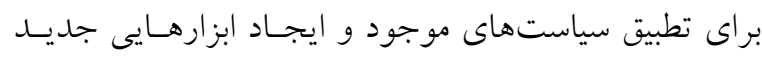

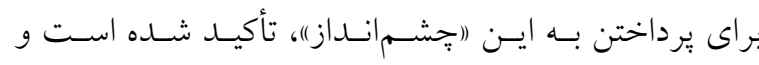

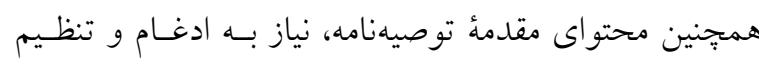

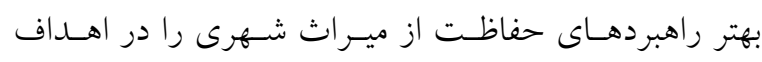

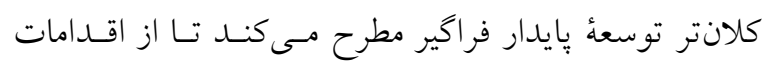

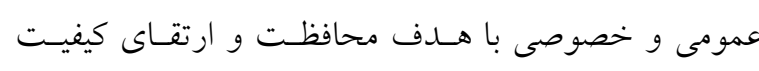

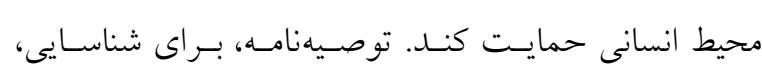

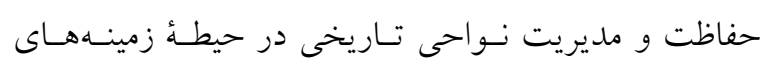

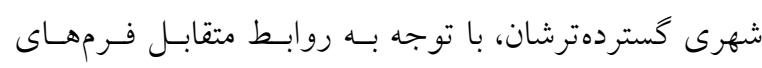

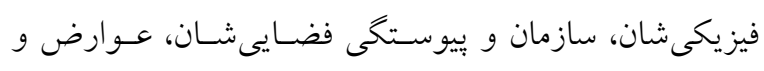

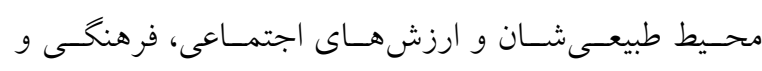

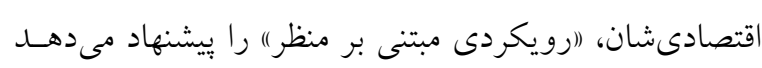

.(UNESCO 2011, Atrs. 4, 5)

اين رويكرد، به دليل سه جنبهُ شاخص خود قابـل تعمـيم

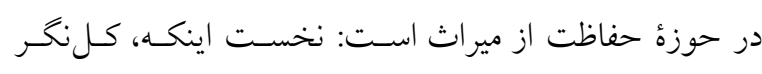
(Holistic)

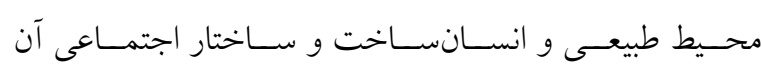

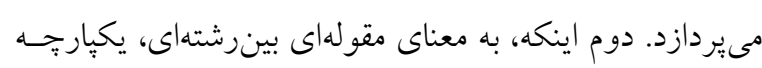

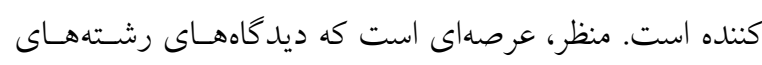

هيدرولوزى و عوارض طبيعى سايت، محيط انسانسـاخت آن

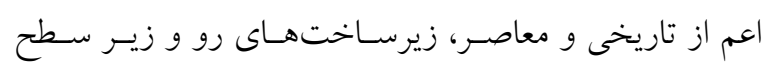
زمين، فضاهاى باز و باغها، الكوهاى كاربرى زمين و سـازمان ونسان

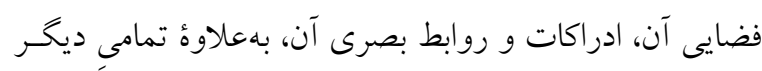

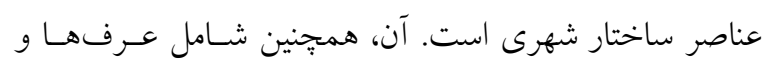

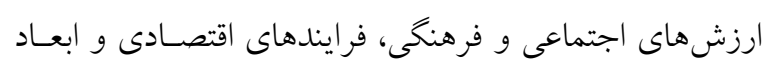

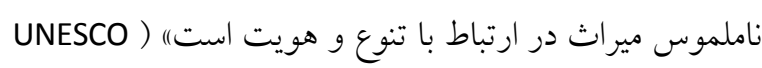

(2011, Art.9

مفهوم (لاليهبندى تاريخى ارزشهـا) در توصسيهنامـه، بـهـ

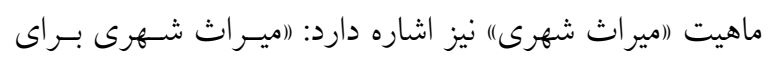

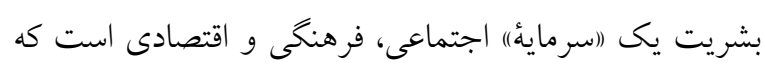

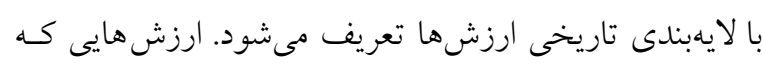

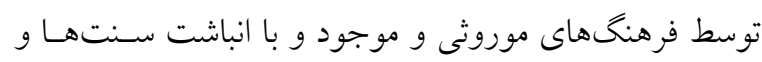

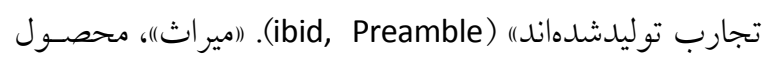

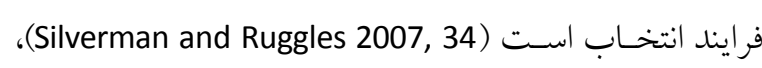

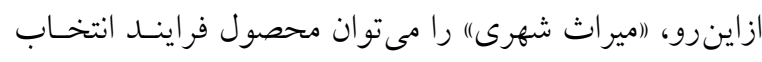

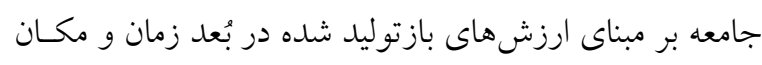

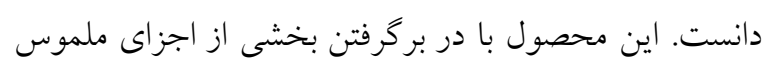

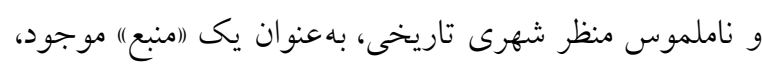

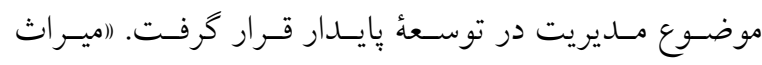
شهرى، شامل بر اجزاى ملموس و ناملموس آن، يـك (منبـع)"

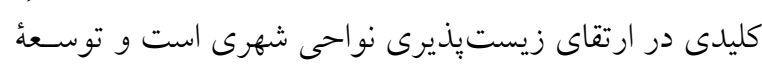
اقتصادى و انسجام اجتماعى را در يكى محيط جهانى در حسال تغيير، تقويت مى كند) (UNESCO 2011, Art.3).

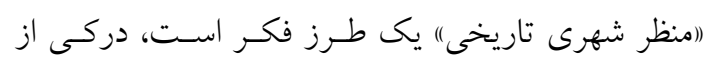

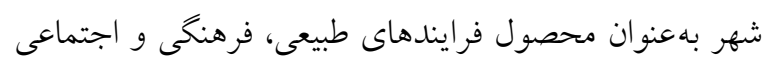

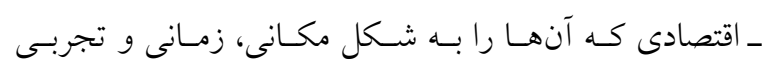

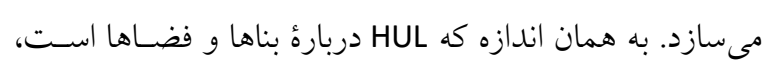

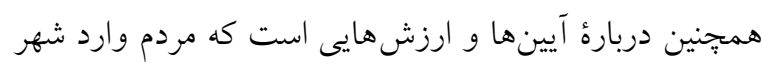

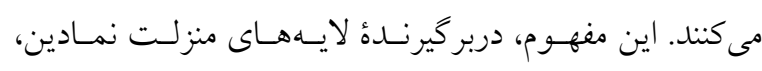

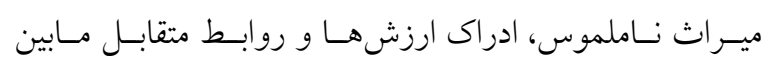

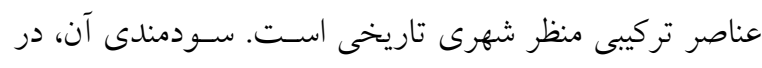

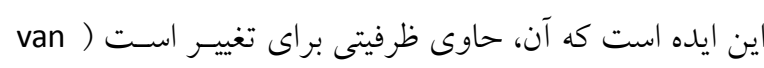

(Oers 2010, 14 
يرمخاطـب (مـان)" (R.E. Munn)، (ارزيـابى اتــرات محيطى)"، عبارت است از: (افرايـــى بــراى شناسـايى عواقـب احتمـالى ناشى از اجراى فعاليتهايى خاص بر محيط بيوزئسوفيزيكى و سلامت و رفاه انسان و انتقال ايـن اطلاعـات بـهـ افـرادى كـهـ مسئول تصويب يِيشنهادها هستند، در مرحلهاى كـه مسىتوانـد

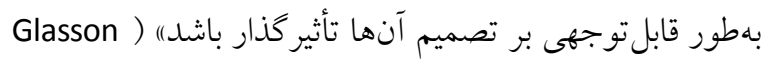
(et al. 1999, 3 براى محيط انسانى، توسط ابزار (ارزيابى اثرات ميراثى)" (HIA) مورد تحليل قرار مى گيرد (ICOMOS 2011). بهاين ترتيب، رويكرد HUL بر گسترهاى سرزمينى دلالـت

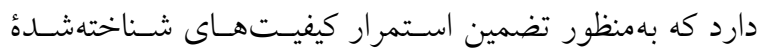
محيط انسانى، هركونه تغييرى را كه آنها را تهليـــ مسىكنـد،

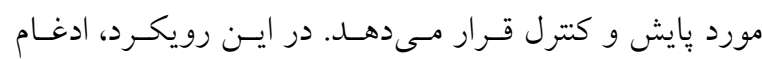

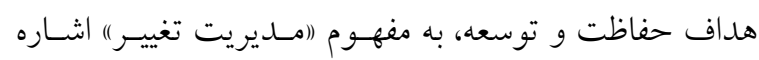
دارد. در حوزهُ حفاظت از ميراث فرهنخـى، فراينـد (امـديريت

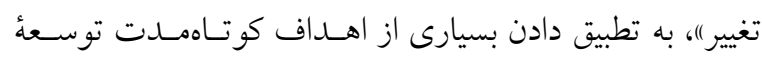
تسهيلات، با منافع نسل هاى آينده در حفـظ منزلـت فرهنخى ميراث اشاره دارد. هرجند كه در اين فرايند ممكن است نسـل Pاضـر، حسائز اهميـت تلقـى شـوند ( Poders \& .(Hudson 2011, 175 از طرفى، (ارويكرد HUL، با مطرح كردن تنوع فرهنخى و خلاقيت بهعنوان سرمايههـاى كليـدى بــراى توسـعة انسـانى، اجتماعى و اقتصادى، ابزارهـايى را بــراى مـــيريت تغييـرات فيزيكى و اجتماعى فراهم مى كند و جهت حصول اطمينـان از اينكه مداخلات معاصر در بسترى تـاريخى در همـاهنكى بـا ميراث ادغامشدهاند، زمينههاى منطقهاى را در نظـر مسى گيـرده) (UNESCO 2011, Atr. 12) بهايـن ترتيـب در رويكـرد منظـر

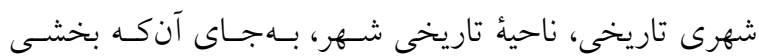

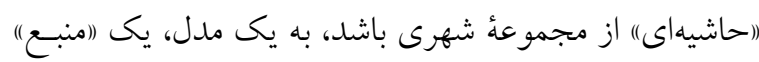

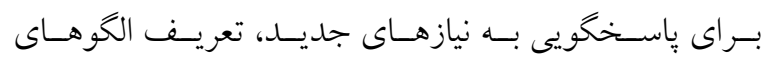

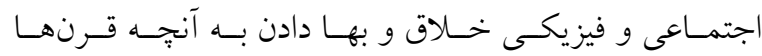
تجربهورزى در طراحى فضاها و فرم شهرى به ما اعطا كرده،

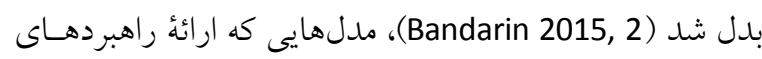

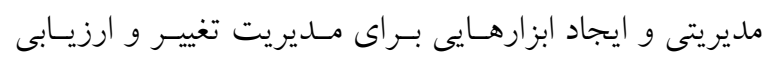

مختلف مرتبط با شهر را با توجه به رويكردهاى علوم طبيعى و انسانى و نيز ابعاد فيزيكى و ناملموس ميراث، ادغام مىكند. سوم اينكه، مبتنى بر ارزش است. به ايسن معنــا كـه منظـر بــر

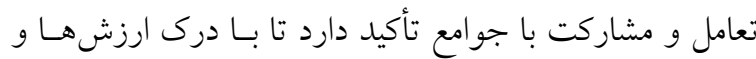
منزلت فرهنكى، بتواند از كفتمانى بين فرهنكى ميان ذىنفعـان

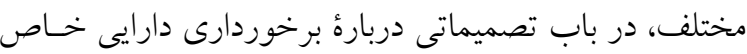
از منـافع حفاظـت، حمايـت كنــ ) Ginzarly et al. 2019,

هدف توصيهنامه از اخذ رويكـردى مبتنى بـر منظـر، در عين شكوفايى شـهرها، مـــيريت (اسـتمرار)" (Continuity) و

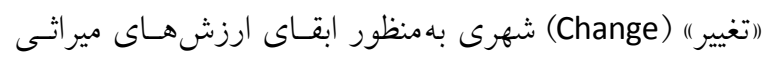

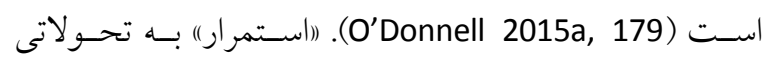

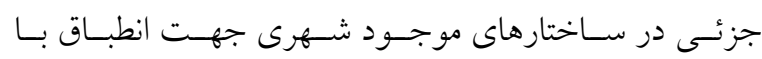
فعاليتها و سبكهاى جديدِ زندكى شهرى اشـاره دارد؛ و در

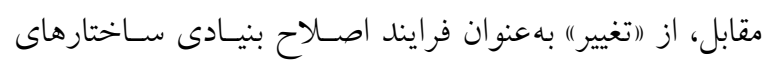

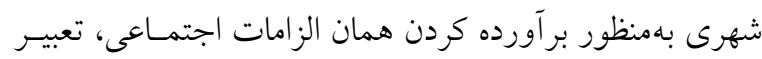
شده است. استمرار و تغيير، بىشـك فراينـدهايى هسـتند كـه بنيان هر فرهنگ يا جامعلُ شهرى را شكل مىدهند (Zancheti .(\& Jokilehto 1997, 39 "ارويكرد منظر شهرى تاريخى با بالا بردن كـاربرى يربـار" و بايدار فضاهاى شهرى، ضمن شناخت سرشت بوياى آنهـا و با تقويت تنوع اجتمـاعى و عملكــردى آنهـا، محافظـت از كيفيت محيط انسـانى را مـورد هـــف قـرار داده اسـت. ايسن رويكرد، اهداف حفاظت ميراث شهرى را بـا اهـــاف توسـعة اجتماعى و اقتصادى ادغام مى كند. اين امر، ريشه در رابطـهاى متعادل و وپايدار بين محسيط شهـرى و طبيعى، بـين نيازهـاى نسل هاى حاضر و آينده و ميراث برجاىمانده از كذشته دارده) .(UNESCO 2011, Atr. 11)

در اين تعريف، وازهة (امحسيط انسـانى)، محسيط طبيعى و فيزيكـى و ارتبـاط مــردم بــا آن محسيط را در برمسى گيسرد و محافظت از كيفيت محيط انسانى بـهـ مقولـه (ارزيـابى اثــرات

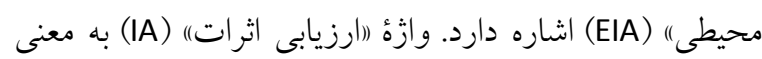
"(فرايند شناسايى بيامدهاى آتى يكى اقدام جارى يا بيشـنهادى")

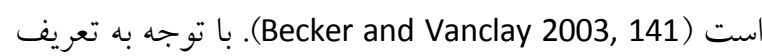


و از منظر بهعنوان مقياس تحقيق استفاده مىكنـد ( Using the اثرات مير اثى را ميسر مى كنند.

(مقياس) landscape

سياست دوم با كاربرد ("رويكــد منظـر يكيارجــه (ILA)، (ILA)، كوياى هدف اصلى توصيهنامه است، جر اكه (امديريت تغييـر) در نواحى شهرى تاريخى، بهمنزلة فرصتى براى ارتقاى كيفيت

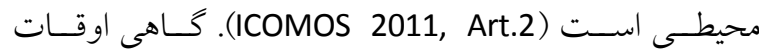
"رويكرد منظر بخشى") به دليل محــدوديتهـايى در ظرفيـت،

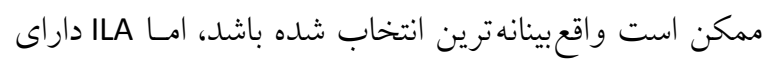

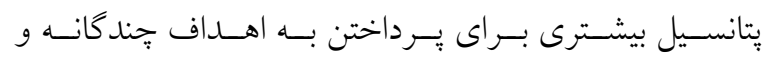

جالش هاى بيّيجيده است (Freeman et al. 2015, 33).

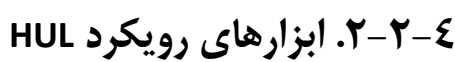

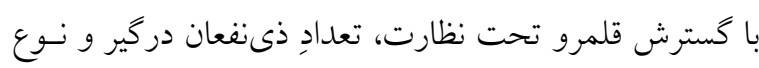

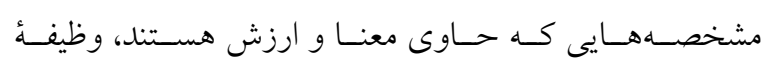
متخصصان شهرى و مديران محوطهها بغرنجتر مىشـود. ايسن

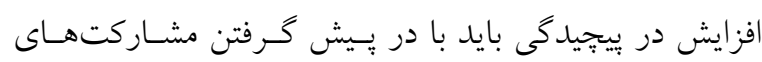

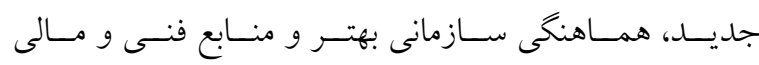
دسترسيذيرتر، متعادل شود. مديريت موفق ميراث شهرى در محيطهاى يبيجيده كه رويكرد منظر شهرى تاريخى براى آنها توسعهيافته است، نيـاز بــه جعبـهابـزارى قدرتمنـــ دارد. ايـن مجموعه، بايد حاوى طيف وسيعى از ابزارهاى ميانرشتهاى و مبتكرانسه باشــ (Bandarin and van Oers 2012, 143-4). "رويكرد HUL، به كاربرد طيف وسيعى از ابزارهاى مرسـوم و نو آورانهُ متناسب با زمينههاى محلى اشاره مسىكنـد. برخسى از اين ابزارها كه بايد بهعنوان بخشى از فرايند تعامل با ذىنفعان

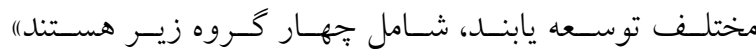
:(UNESCO 2011, 24)

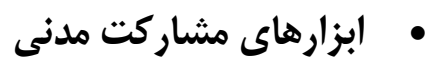

(ابزارهاى مشاركت مدنى، بايد مقاطع متنوعى از ذى إنفعـان را

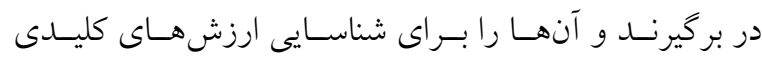

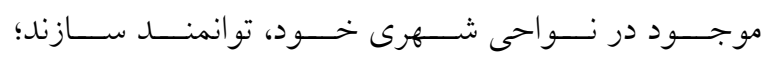
جشم اندازهايى را كه منعكس كنندهُ تنوع آنها اسـت، توسـعه

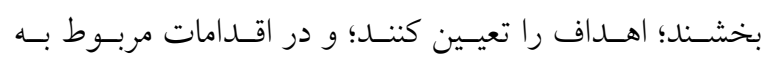

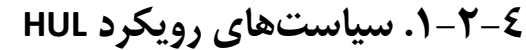
(اسياسـتهــاى مــدرن حفاظـت شـهرى، همـانكونـه كـه در توصيهنامهها و منشورهاى بين المللى موجـود انعكـاس يافتـه، زمينهاى را براى محافظت از نـواحى شـهرى تـاريخى فـراهم

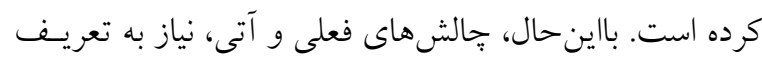

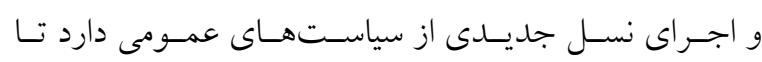

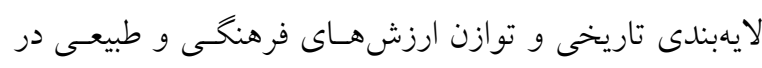

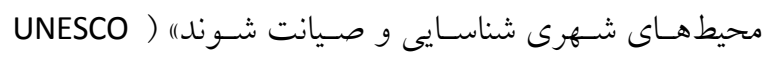

(2011, Atr. 21

ازاينرو، سياستهاى اخذشده از سوى رويكرد HUL بـاسـا

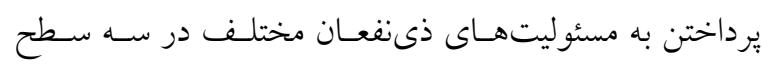
محلى، ملّى و فر املّى، سه مقولئ اصلى را شامل مىشوند: (1 (1)

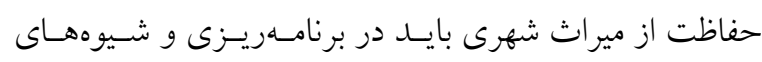

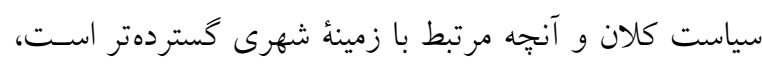

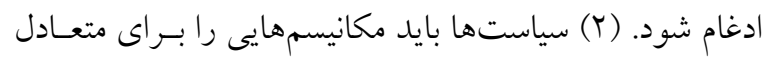
كردن حفاظت و بايدارى در كوتاهمــت و بلندمـــت فـراهم كنند. (r) بايد تأكيد ويزهاى بر ادغام موزون مداخلات معاصر در بافت شهرى تاريخى شود) (ibid, Art.22). اين سه سياست، بر مبناى حوزهُ تمركز، رويكرد و آنجهـ

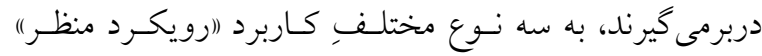
اشاره دارند (Freeman et al. 2015, 24-26). اصـل نخسـت،

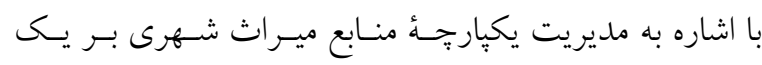

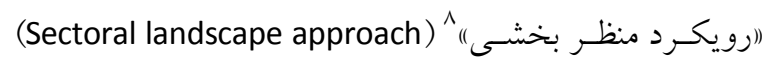

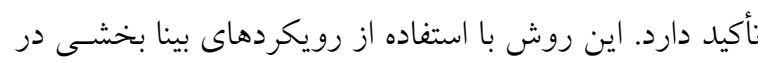
مديريت منابع جهت دستيابى به اهداف بخشيى از فراينـدهاى

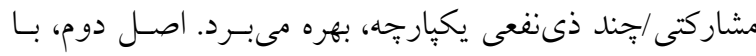

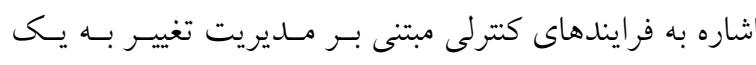

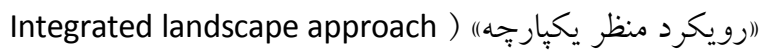
(ILA) براى تبيين منطق تغييـر و يـا روشـن كـردن اهــاف اسـتفاده

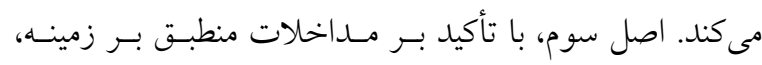
درك الكوها و فرايندها را در مقياس منظر، هدف قرار مى دهد 
نقشهبردارى از مشخصههاى فرهنخى و طبيعى را در بركيـرد.

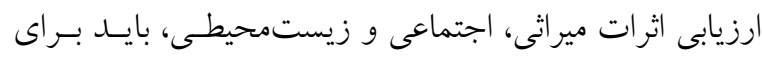

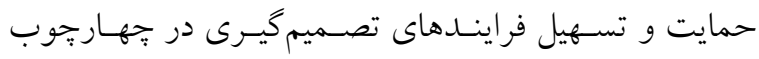

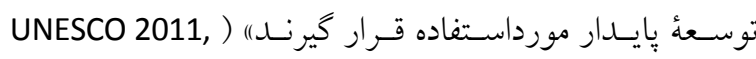

.(24(b)

ابزارهاى مورداشاره در اين خـروه، اغلـب، بـهـ مجموعـهـ

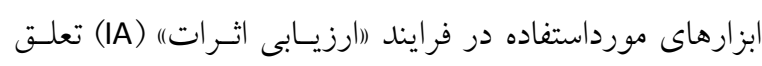

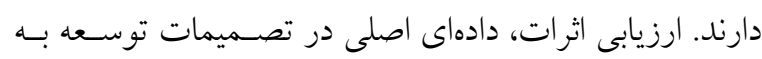

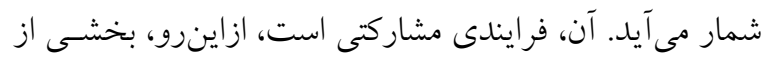

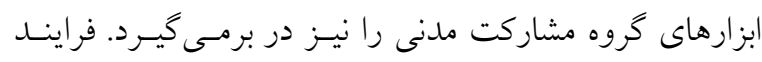

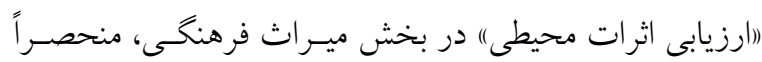

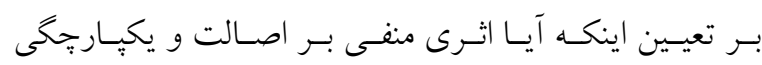

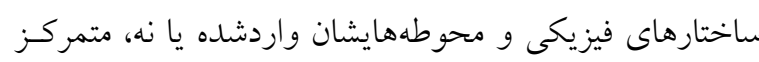

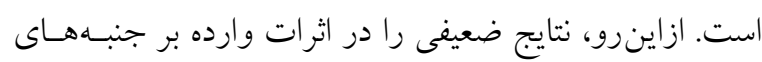

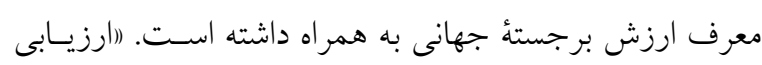

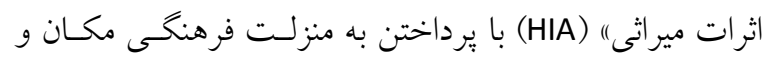

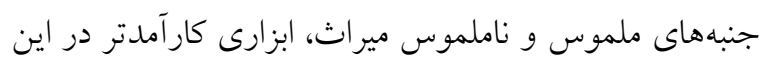

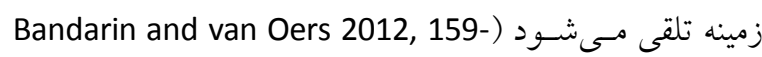

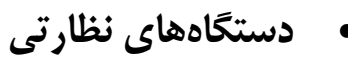

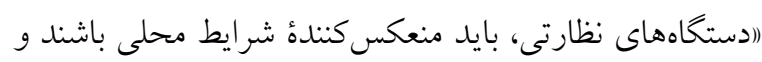

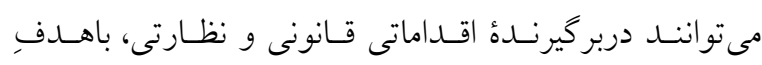
حفاظت و مديريت ويزّكى هاى ملموس و نـاملموس ميـراث

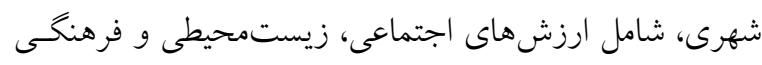

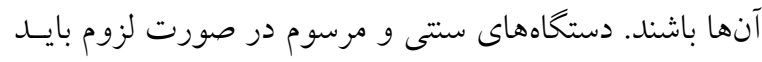

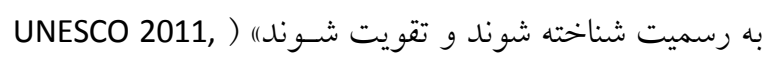

(24) (c)

دستخاههاى نظارتى گروهى از ابزارها را دربرمى گيرند كه

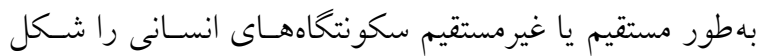

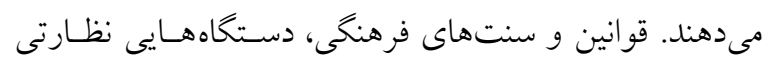

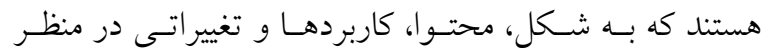

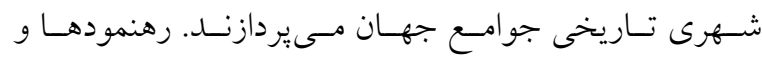

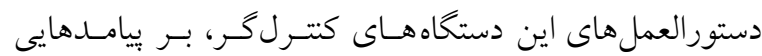

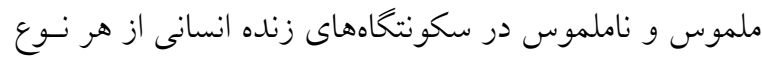

صيانت از ميراث آنها و ترويج توسعه بِايدار به توافق دسـت

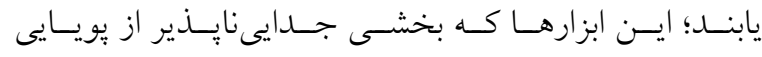

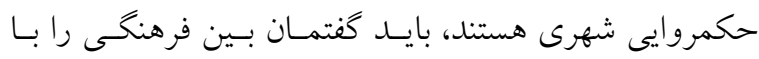

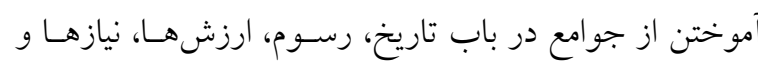

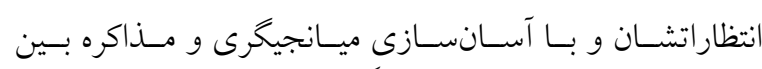
كروههايى با تضاد منافع، تسهيل كنند) (a) (abid, 24).

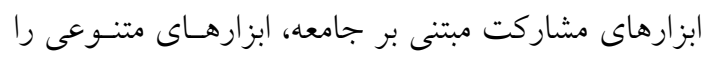

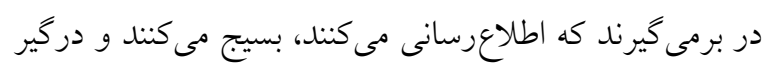

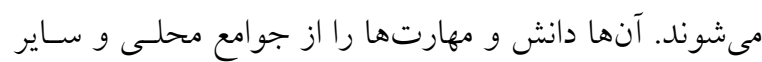

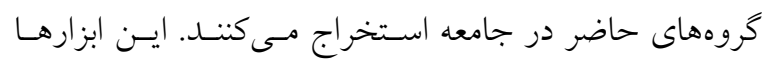

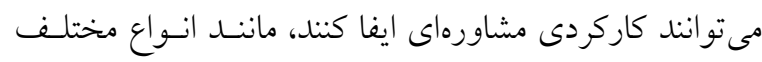

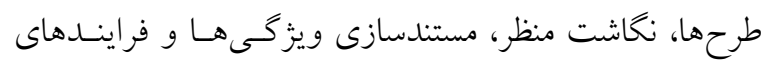

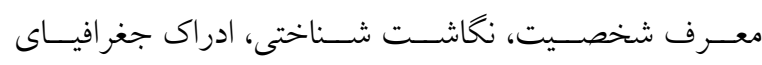

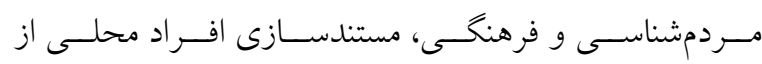

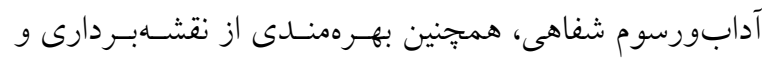

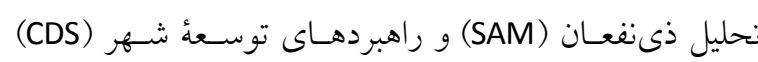

.(Bandarin and van Oers 2012, 155) تحقيقات نشان مىدهند كه مشـاركت بــواسطة انخيـهن،

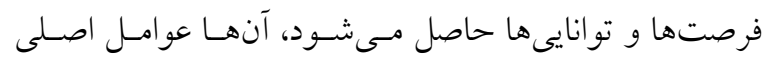

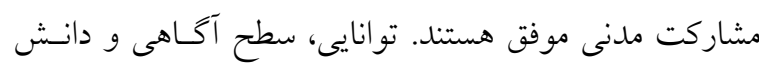

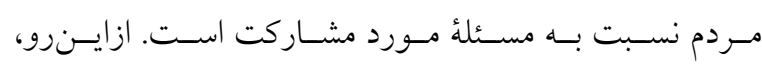
ظرفيتسازى براى ذىنفعان، رويكرد بـين نسـلى نسـبت بـهـ

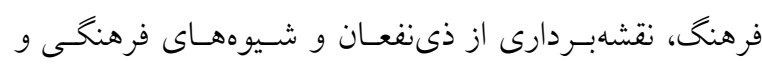

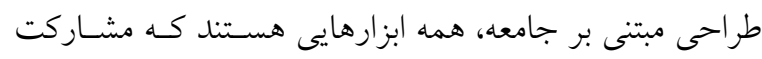

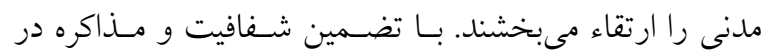

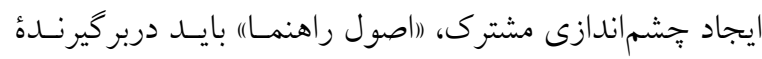
همهُ اقشار جامعه در فرايندهاى تصميمخيـرى باشـــ ( Erkan

.(2019, 193-4

\section{ابز ارهاى دانش و برنامهريزى}

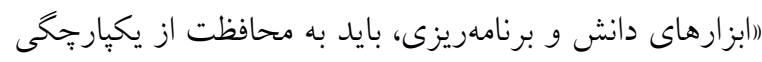

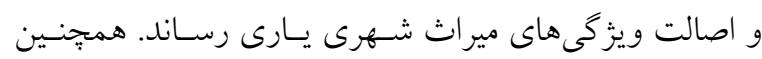

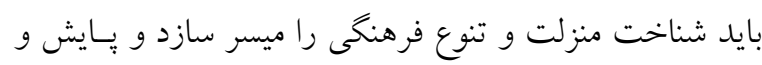

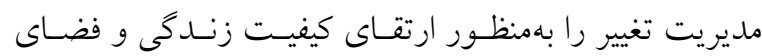

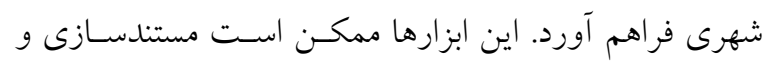


بسـتن شـكاف بـين هزينـه و ارزش لازم باشــند تـا وجــود ارزشهاى دريافت شده توسط جامعهُ بزرگتر را به رسـميت

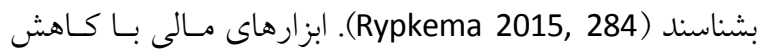
هزينه، افزايش درآمد، كـاهش خطريــيرى و افـزايش سـطح اشتغال، بـهـ بسـتن شـكاف يـارى مـى كنـــ. اسـتفاده از انـواع مــلهـاى مشــاركتى ريشـهدار در فرهنـع محلـى، فراتـر از مدلهــاى دولتى ـ عمـومى و دولتسى ـ خصوصى، موجـبـ عصول اطمينان از يايدارى مدلهاى مـالى مسىشـود ( Erkan .(2019, 195

بهاين ترتيب، سياستهــاى رويكـرد HUL بـا اسـتفاده از

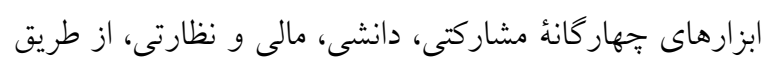

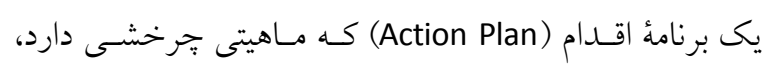
قابل حصول است (Erkan 2019, 190).

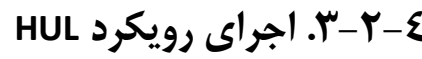

در سى و ششمين مجمع عمـومى يونسـكو، در نـوامبر سـال 11 أr م.، خطاب به اعضاء براى تسهيل اجراى رويكرد منظر شهرى تاريخى، حداقل شش مرحله يا كام مهم توصسيه شـد.

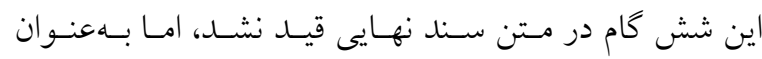
جهارجوبى نظرى توسط بخش آموزش يونسكو توسعه يافت

:(WHITRAP 2016, 13)

1- انجام بررسىهاى جامع و نقشهبــدارى از منـابع طبيعى،

$$
\text { فرهنگى و انسانى شهر؛ }
$$

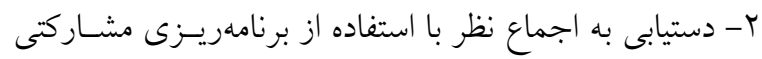

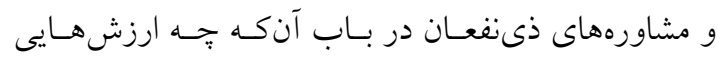
به منظور انتقال به نسلهاى آينده بايد تحت حفاظت قـرار

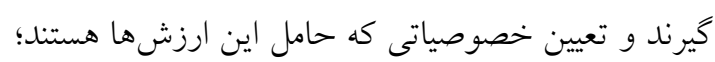

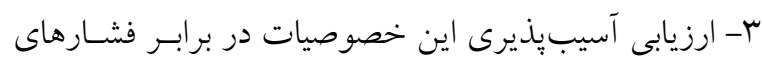
اقتصادى ـ اجتماعى و تأثيرهاى تغييرات اقليمى؛ لئى

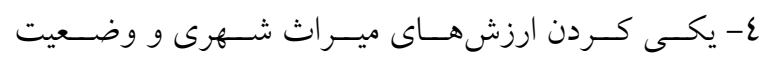

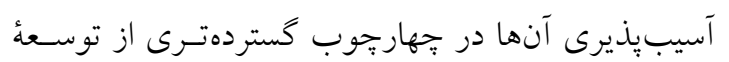

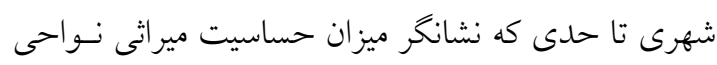

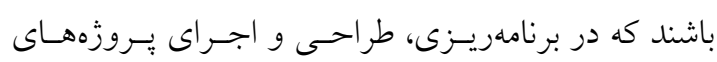

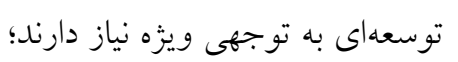

و اندازهاى، تأثير مى كذارند. قوانين موجود در سـطح محلى،

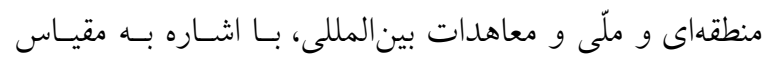

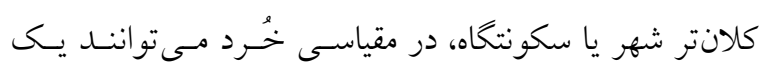
دارائى شخصى را دربر گيرند. امروزه طرحهاى نظارتى عمومـاً به مباحثى مانند ساختوساز سبز، باسخ به تغييرات اقليمسى و

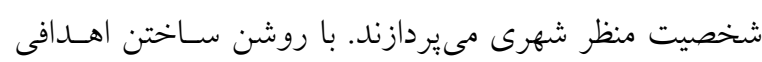
براى ميراث شـهرى جهـت سـوق دادن حفاظـت شـهرى در ماتريس نيازهاى سرزندكى شهرى، بر ميزان موفقيت رويكـرد

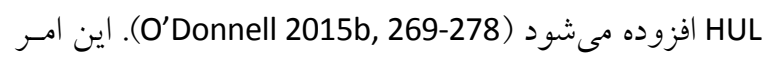

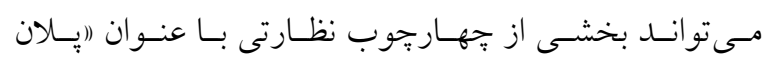
مديريت) باشد كه تحت مديريت ميراث شـهرى قـرار دارد و

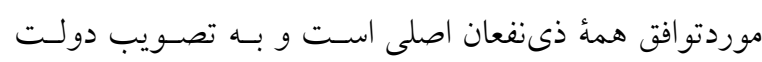

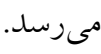

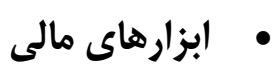

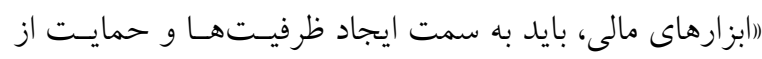

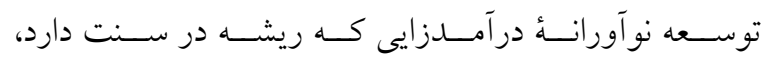
هدف گذارى شوند. علاوه بر كمكهاى مالى دولتى و جهـانى

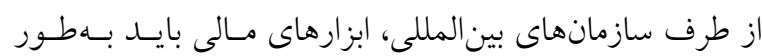
مؤثر براى تقويت سرمايه گذارى خصوصى در سـطح محلى به كار كرفته شوند. اعتبارات خُرد و ساير منابع مالى با قابليت

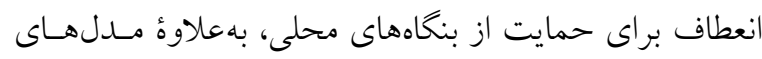

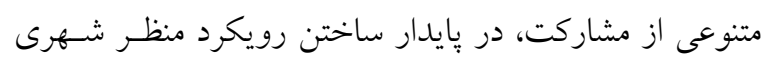
تاريخى ازنظر مـالى، از اهميـت اساسـى برخــوردار هسـتند) .(UNESCO 2011, 24(d))

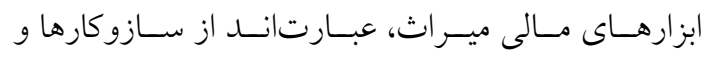
برنامههـيى كـهـ بـراى تشـويق و تسـهيل سـرمايهكـذارى در

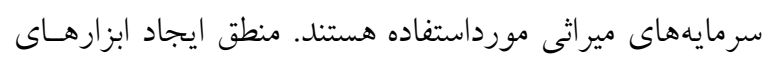

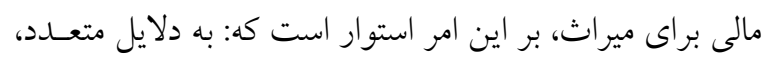

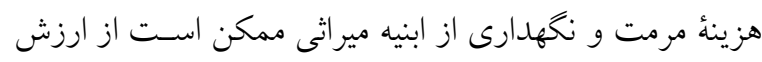

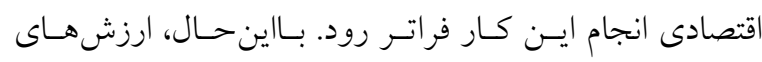

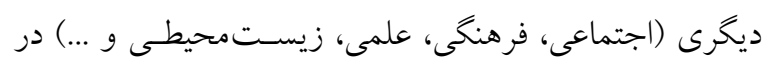

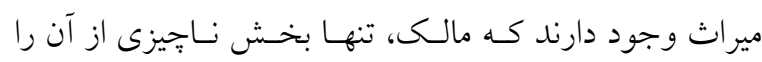

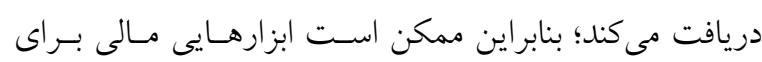


ناشـى از توسـعةُ اجتمـاعى ــ اقتصـادى بــر ميـراث شـهرى، يكهارجه كـردن توسـعة شهرى و مــديريت منـابع ميراتـى را بهمنظور (استمرار)) هويت شهرى و كتترل فراينـدهاى ((تغييـر)" مورد هدف قرار داده است (جدول (). در دو دهأ اخير (رويكرد منظر)" در حوزه محيطزيست

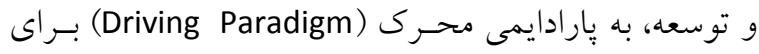
برقرارى تعادلى كـل نكرانـه بـين اهـداف زيسـتمحيطى و اجتماعى تبديلشده است، باين حال، علىرغم ادبيات غنس،

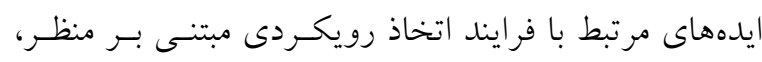
متنوع و غالباً مبهم بودهاند (Freeman et al. 2015, 24). در تر تر

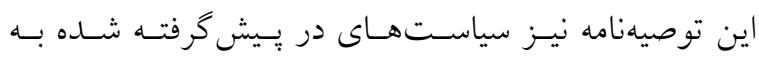
روشهاى مختلف اعمال (رويكــرد منظـر)، شـامل (اكـاربرد

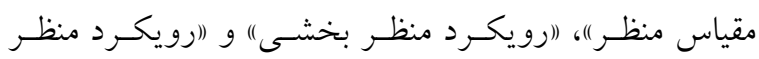

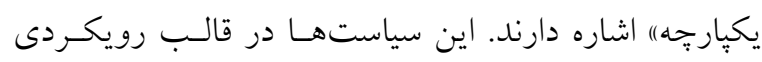

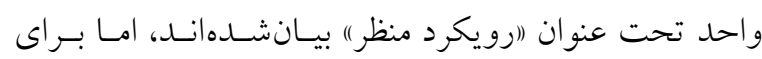
عملياتى شدن، مستلزم اتخــاذ فراينـدهاى متمـايز مبتنى بـر

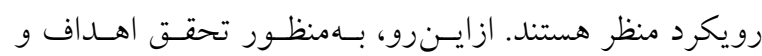
سياستهاى رويكرد HUL، بايد كاربرد ابزارهـاى جهار گانـأ توصيهنامـه بـا روش هـاى مختلـف اعمـال رويكـــد منظـر، بازتعريف و متناسب شوند.
0- اولويتبندى اقدامات مربوط به حفاظت و توسعه؛ و 7- ايجاد مشاركتهاى مناسب و جهـارجهوبـهـاى مـديريت محلى براى هر يك از بروزههاى تعريف شـــه مربـوط بـهـ

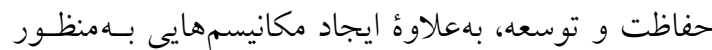
هماهنگ كردن فعاليتهاى مختلـف مـابين نقـش آفرينـان UNESCO 2011, 50; ) متفاوت، اعم از دولتى و خصوصى لتسي

(Pereira Roders and Bandarin 2019, 40

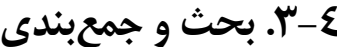

توصيهنامه در مقدمةٔ سند، ضمن به رسميت شـناختن ماهيـت يوياى شهرهاى زنده و با اشاره به دگرگونى نواحى شـهرى و

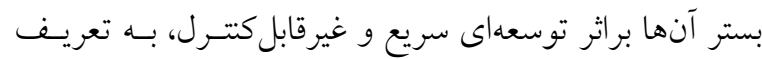

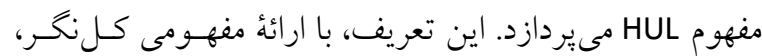
بينرشتهاى و مبتنى بر ارزش از محيط تاريخى، زمينـهُ اتخـاذ

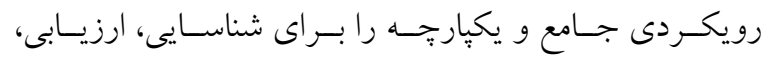
حفاظـت و مــديريت منظرهـاى شـهـرى تـاريخى در قالـبـ جهارجوب ("توسعة بايدار فراخير)" فراهم مسى آورد ( UNESCO

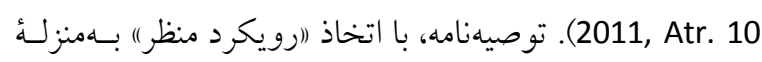

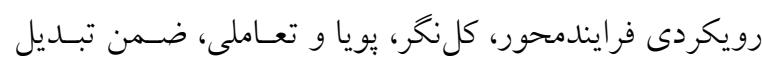

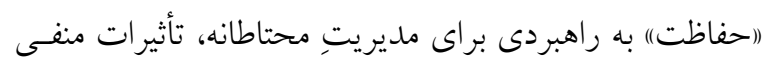

\section{نتيجه كَيرى}

بهو اسطة كاربرد طيفى از ابزارهاى سنتى و نو آورانه در انطبـاق با زمينههاى محلى، پِيهاى را براى ادغام حفاظـت شـهرى در

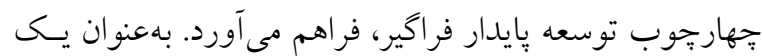
("مفهوم)، منظـر شـهرى تـاريخى بـا كمـك كـردن بـه مـا در شناسايى عناصر بيبجيدهاى كه شهرهايمان را متمايز مىسازد و

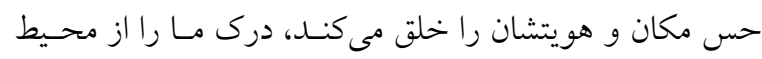
تاريخى بيشتر مى كند. درى شهرهايمان به اين طريق، براى ما دانشى ارزنده را در جهت هدايت تصـميمات برنامسهريـزى و

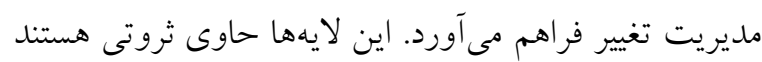

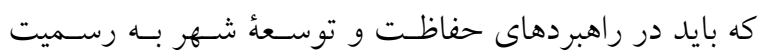

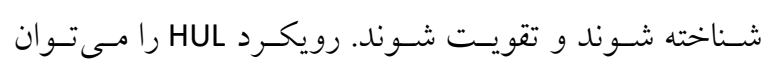

منظر شهرى تاريخى (HUL) رويكردى جـامع و بــينرشـتهاى

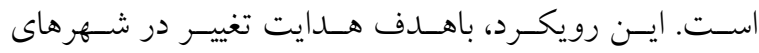
تاريخى، مديريت فراخير منابع ميراثى در محسيطهـاى بويــا و همواره در حال تغيير را موردتوجه قرار داده است. ايسن امـر،

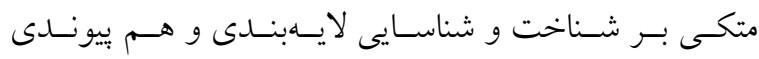

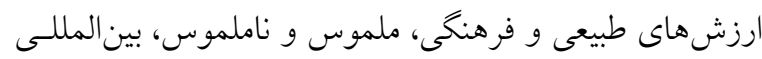
و محلى موجود در هر شهرى اسـت. مطسابق رويكـرد منظـر شهرى تاريخى، اين ارزشها بايد بهمنزلهُ (نقطسه حركتى) در

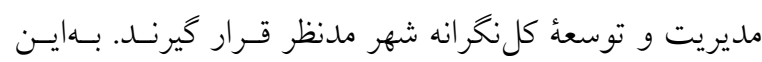

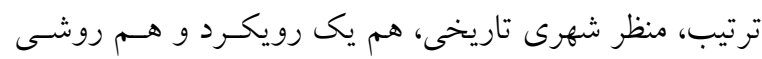
جديد براى درك شهرهايمان است: بهعنوان يـك (رويكـرد)، 
بهتر اينكه جخونه HUL در عمـل شـكل مـى گيـرد و تعريـف

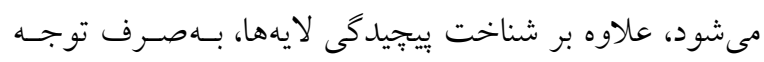

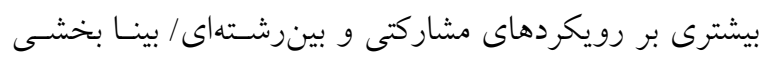

مرتبط با روشهاى مختلف بهكـار گيرى رويكــــ منظـر، نيـاز
بهمنزلهُ نسل جديدى از برنامهريـزى شـهرى تلقـى كـرد كـه

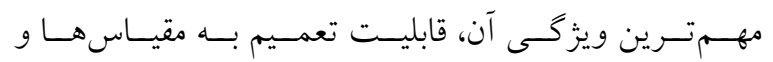

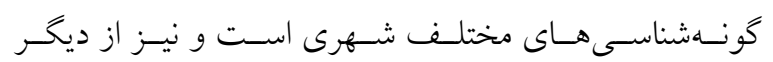

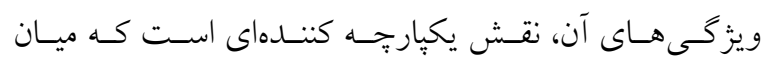
شبكهاى متنوع ذىنفعان ايفا مى كند. باين حال بهمنظور درى

جدول (: مفاد توصيهنامه II إب يونسكو درباره مفهوم و رويكرد منظر شهرى تاريخى.

Table 1: The Contents of UNESCO 2011 Recommendation on the HUL concept and approach.

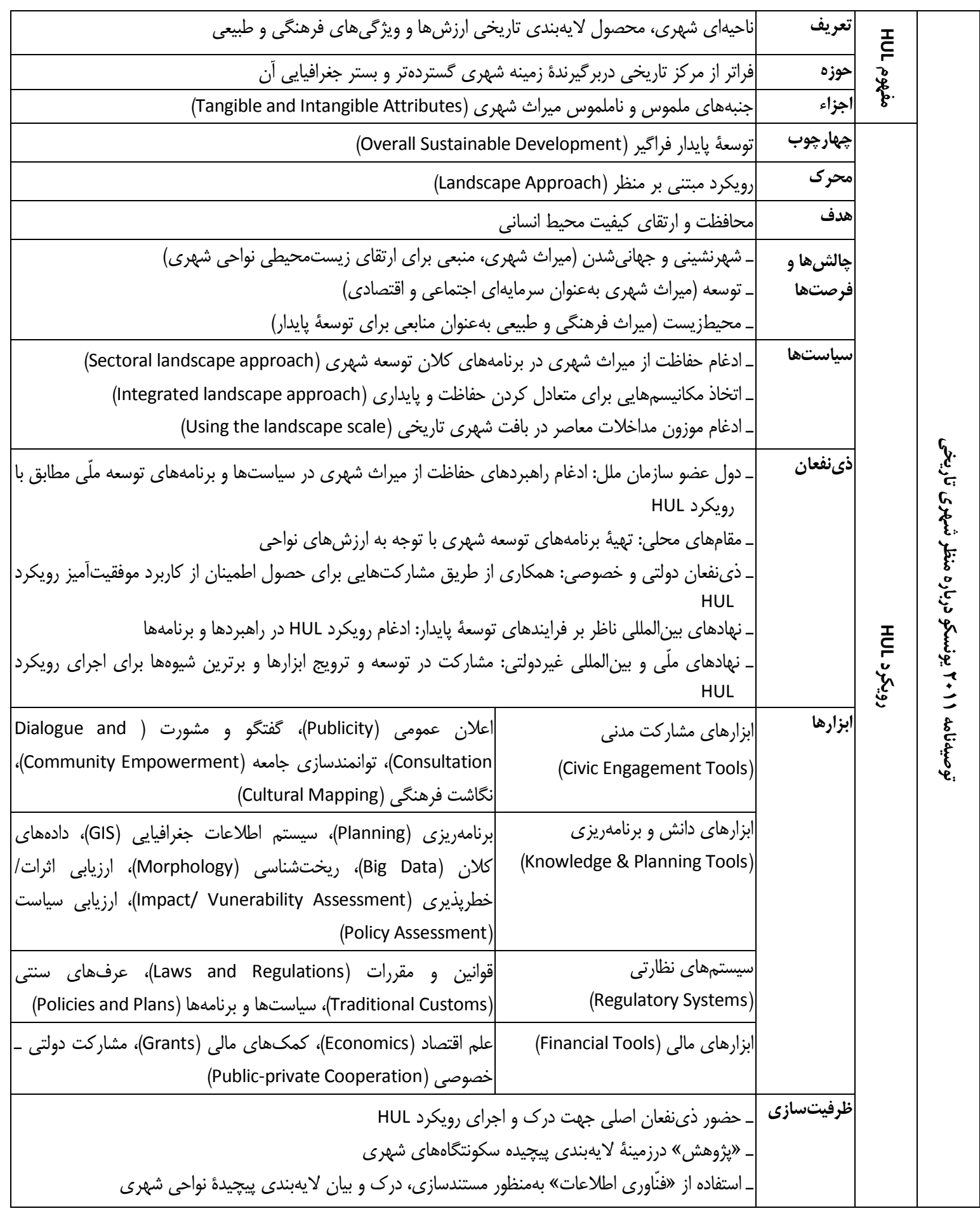


رويكرد منظر شهرى تاريخى ابزارى جديد براى مديريت ميراث شهرى

\section{يحىنوشتها}

1. The Recommendation on the Historic Urban Landscape, adopted by the 36th session of the UNESCO, Paris, 2011.

2. The UNESCO Convention Concerning the Protection of the World Cultural and Natural Heritage (WHC: The World Heritage Convention), Paris, 1972.

$$
\text { ب. منزلت فرهنكى (Cultural Significance) به معناى مجموعهاى از ارزش هاى منتسب به يك مكان است. }
$$

4. Vienna Memorandum on "World Heritage and Contemporary Architecture - Managing the Historic Urban Landscape" adopted by UNESCO in 12-14 May 2005 in Vienna.

5. Jerusalem (June 2006), Saint Petersburg, Russian Federation (January 2007), Olinda, Brazil (November 2007), Zanzibar, Tanzania (December 2009) and Rio de Janeiro, Brazil (December 2009), in addition to three planning meetings held at UNESCO Headquarters (September 2006, November 2008 and February 2010).

7. ترجمه كتاب (منظر شهرى تاريخى: مديريت ميراث در قرن شهرى) در سال 90با توسط مؤسسه انتشارات دانشگاه تهران منتشرشده است.

V. بازتوليد اجتماعى (Social Reproduction) فرايندى است كه بهواسطة آنيكى جامعه/ نظام اجتماعى خود را از نسلى به نسل ديخر بازتوليد مى كند.

ᄉ بخش (Sector) بهمنزله قسمتى از جامعه تعريف مى دود كه در آن ذىنفعان مختلف، ارزش اقتصادى و اجتماعى ايجاد

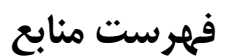

Angrisano, M., P. F. Biancamano, M. Bosone, P. Carone, et al. 2017. Towards operationalizing UNESCO recommendations on Historic Urban Landscape: A position paper. Aestimum (69): 165-210. https://doi.org/ 10.13128/Aestimum-20454

Australia ICOMOS. 1999. The Burra Charter: The Australia ICOMOS Charter for Places of Cultural Significance. 1979; rev. 1999. Burwood: Australia ICOMOS. Available from: https://australia.icomos.org/wp-content/ uploads/The-Burra-Charter-2013Adopted-31.10.2013.pdf (accessed 10 October 2019).

Bandarin, F. 2015. Introduction: Urban Conservation and the End of Planning. In Reconnecting the City, eds. Francesco Bandarin, \& Ron van Oers, 1-16. Chichester: Wiley Blackwell.

Bandarin, Francesco and Ron van Oers. 2012. The Historic Urban Landscape: Managing Heritage in an Urban Century. Chichester: Wiley Blackwell.

Bandarin, Francesco and Ron van Oers eds. 2015. Reconnecting the City: The Historic Urban Landscape Approach and the Future of Urban Heritage. Chichester: Wiley Blackwell.

Becker, Henk A. and Frank Vanclay eds. 2003. The International Handbook of Social Impact Assessment: Conceptual and Methodological Advances. Cheltenham: Edward Elgar.

Bontje, M. and S. Musterd. 2008. The Multi-layered City: The Value of Old Urban Profiles. Tijdschrift voor economische en sociale geografie 99(2): 248-255.

CoE. 1975. European Charter of the Architectural Heritage, Adopted by the Council of Europe, Amsterdam from 21 to 25 October 1975. Available from: https://www.icomos.org/en/charters-and-texts/179-articles-enfrancais/ressources/charters-and-standards/170-european-charter-of-the-architectural-heritage (accessed 20 December 2019).

CoE. 1995. Recommendation on the Integrated Conservation of Cultural Landscapes Areas as Part of Landscape Policies, Adopted by the Council of Europe Committee of Ministers Recommendation No. R (95) 9 of 11 September 1995. Available from: https://rm.coe.int/16804f6e76 (accessed 10 October 2019).

Corner, James ed.1999. Recovering landscape: Essays in Contemporary Landscape Architecture. New York: Princeton Architectural Press.

Drisko, James W. and Tina Maschi. 2016. Content Analysis. New York: Oxford University Press.

Erkan, Y. 2019. The Way Forward with the Historic Urban Landscape Approach towards Sustinable Urban Development. The Implementation of the UNESCO Historic Urban Landscape Recommendation: Expert Meeting held in Shanghai, China, on 26-28 March 2018, 184-201. Shanghai: WHITRAP.

Esfanjary, Eisa. 2017. Persian Historic Urban Landscapes: Interpreting and Managing Maibud Over 6000 Years. Edinburgh: Edinburgh University Press.

Fairclough, Graham, Rodney Harrison, John H. Jameson, and John Schofield eds. 2008. The Heritage Reader. London; New York: Routledge.

Freeman, O. E., L. A. Duguma, and P. A. Minang. 2015. Operationalizing the integrated landscape approach in practice. Ecology and Society 20(1): 24-43. 
Ginzarly, M., C. Houbart and J. Teller. 2019. The Historic Urban Landscape approach to urban management: a systematic review. International Journal of Heritage Studies, 25(10): 999-1019.

Glasson, John, Riki Therivel and Andrew Chadwick. 1999. Introduction to Environmental Impact Assessment: Principles and Procedures, Process, Practice and Prospects. London \& New York: Routledge.

Hsieh, H. F. and S. E. Shannon. 2005. Three Approaches to Qualitative Content Analysis. Qualitative Health Research 15(9): 1277-88.

ICOMOS. 1964. International Charter for the Conservation and Restoration of Monument and Sites (The Venice Charter 1964), Ind International Congress of Architects and Technicians of Historic Monuments, Venice, 1964; Adopted by ICOMOS in 1965. https://www.icomos.org/charters/venice_e.pdf (accessed 10 May 2019).

ICOMOS. 1987. Charter for the Conservation of Historic Towns and Urban Areas (Washington Charter 1987), Adopted by ICOMOS General Assembly in Washington, DC, October 1987. https://www.icomos.org/charters /towns_e.pdf (accessed 10 October 2019).

ICOMOS. 1994. The Nara Document on Authenticity (1994), Adopted by ICOMOS Symposia, Nara, Japan, 1-6 November 1994. Available from: https://www.icomos.org/charters/nara-e.pdf (accessed 10 October 2019).

ICOMOS. 2011. Guidance on Heritage Impact Assessments for Cultural World Heritage Properties. Paris: International Council on Monuments and Sites. Available from: https://www.icomos.org/world_heritage/ HIA_20110201.pdf (accessed 10 October 2019).

ICOMOS Brazil. 1987. First Brazilian Seminar about the Preservation and Revitalization of Historic Centers (Carta de Petropolis), Adopted by the ICOMOS Brazilian Committee, Itaipava, July 1987. Available at: https://www.icomos.org/en/resources/charters-and-texts/179-articles-en-francais/ressources/charters-andstandards/194-first-brazilian-seminar-about-the-preservation-and-revitalization-of-historic-centers-itaipava (accessed 10 October 2019).

Jokilehto, Jukka. 2007. International Charters on Urban Conservation: Some Thoughts on the Principles Expressed in Current International Doctrine. City \& Time 3(3): 23-42.

Matthews, John A. and David T. Herbert. 2008. Geography: A Very Short Introduction. New York: Oxford University Press.

O'Donnell, P. 2015a. Historical Urban Landscape: A new UNESCO Tool for a Sustainable Future. In Conserving Cultural Landscapes: Challenges and New Directions, eds. Ken Taylor, Archer St. Clair and Nora J. Mitchell, 163-181. Routledge studies in heritage. New York: Routledge.

O'Donnell, P. 2015b. The Role of Reglatory Systems. In Reconnecting the City, eds. Francesco Bandarin, \& Ron van Oers, 269278. Chichester: Wiley Blackwell.

Pendlebury, John. 2009. Conservation in the Age of Consensus. London: Routledge.

Pereira Roders, Ana and Francesco Bandarin eds. 2019. Reshaping Urban Conservation: The Historic Urban Landscape Approach in Action. Switzerland: Springer Nature.

Pereira Roders, A. and J. Hudson. 2011. Change Management and Cultural Heritage. In Facilities Change Management, ed. Edward Finch, 175-189. Chichester: John Wiley \& Sons.

Rössler, M. 2015. World Heritage Cultural Landscape: 1992-2012. In Conserving Cultural Landscapes: Challenges and New Directions, eds. Ken Taylor, Archer St. Clair and Nora J. Mitchell, 29-46. New York: Routledge.

Rypkema, D. 2015. Devising Financial Tools for Urban Conservation. In Reconnecting the City, eds. Francesco Bandarin, \& Ron van Oers, 283-290. Chichester: Wiley Blackwell.

Silverman, Heline and D. Fairchild Ruggles 2007. Cultural Heritage and Human Rights. New York: Springer.

Smith, J. 2015. Civic Engagement Tools for Urban Conservation. In Reconnecting the City, eds. Francesco Bandarin, \& Ron van Oers, 221-248. Chichester: Wiley Blackwell.

Sonkoly, Gábor. 2017. Historical Urban Landscape. Cham: Palgrave Macmillan.

Taylor, Ken and Jane Lennon eds. 2012. Managing Cultural Landscapes. Routledge, Key Issues in Cultural Heritage Series. London \& New York: Routledge.

Taylor, Ken, Archer St. Clair and Nora J. Mitchell eds. 2015. Conserving Cultural Landscapes: Challenges and New Directions. Routledge studies in heritage. New York: Routledge.

Turner, M. 2013. UNESCO Recommendation on the Historic Urban Landscape. In Understanding heritage: Perspectives in Heritage Studies, eds. Marie-Theres Albert, Roland Bernecker and Britta Rudolff, 77-87. Bonn: De Gruyter.

UNESCO. 1972. Convention Concerning the Protection of the World Cultural and Natural Heritage (WHC: The World Heritage Convention), Adopted by the UNESCO General Conference at its seventeenth session Paris, 16 November 1972. https://whc.unesco.org/archive/convention-en.pdf (accessed 20 October 2019).

UNESCO. 1976. Recommendation concerning the Safeguarding and Contemporary Role of Historic Areas, Adopted by the UNESCO General Conference at its nineteenth session, Nairobi, 26 November 1976. https:// www.icomos.org/publications/93towns7o.pdf (accessed 10 October 2019).

UNESCO. 2005. Vienna Memorandum on 'World Heritage and Contemporary Architecture - Managing the Historic Urban Landscape'. The UNESCO International Conference on "World Heritage and Contemporary Architecture" held from 12 to 14 May 2005 in Vienna, Austria, The Memorandum adopted by the 29th session of the World Heritage Committee (Durban, 2005). https://whc.unesco.org/en/documents/5965 (accessed 20 November 2019).

UNESCO. 2011. Recommendation on the Historic Urban Landscape, including a glossary of definitions. Records of the General Conference, 36th session, Paris, 25 October - 10 November 2011, Vol. 1: Resolutions, pp. 50-55. https://whc.unesco.org/archive/2005/whc05-15ga-inf7e.pdf (accessed 10 September 2019).

UNESCO. 2019. The UNESCO Recommendation on the Historic Urban Landscape. Report of the Second Consultation on its

$$
\text { | }
$$


رويكرد منظر شهرى تاريخى ابزارى جديد براى مديريت ميراث شهرى

Implementation by Member States, Paris: UNESCO World Heritage Centre.

Van Oers, R. 2010. Managing Cities and the Historic Urban Landscape Initiative - An Introduction. In Managing Historic Cities, eds. Ron van Oers and Sachiko Haraguchi, World Heritage Papers 27: 7-17. Paris: World Heritage Center/UNESCO.

Van Oers, R. and Sachiko Haraguchi eds. 2010. Managing Historic Cities, World Heritage Papers 27. Paris: World Heritage Center/UNESCO.

WHITRAP 2016. The HUL Guidebook: Managing Heritage in Dynamic and Constantly Changing Urban Unvironments. Available from: http://historicurbanlandscape.com/themes/196/userfiles/download/2016/6/7/wirey5prpznidqx.pdf (accessed 5 November 2019).

Zancheti, S. M. and J. Jokilehto. 1997. Values and Urban Conservation Planning some Reflections on Principles and Definitions. Journal of Architectural Conservation 3(1): 37-51. 